\title{
1 Freshwater costs of seawater desalination: Systems process analysis for the case
}

2

4

5 Seawater desalination is one of the most essential strategies to solve freshwater

6 shortage issues worldwide. Though having the possibility of providing abundant

7 freshwater resources, desalination projects are also limited by the pressure of

8 freshwater consumption. Based on the systems process analysis, the freshwater cost of

9 seawater desalination is assessed with the case study of a 25,000 tons/day seawater desalination plant in Huanghua Port, Hebei Province, China. The total embodied water consumption is $9.02 \mathrm{E}+06 \mathrm{~m}^{3}$, which is estimated in magnitude as five percent of the total freshwater production in the design cycle. Among all the sub-projects, the embodied water consumption in the technology system engineering represents the largest component, accounting for $60.12 \%$ of the total. The productivity level of the project is calculated to be 19.29 , which highlights the potential of the desalination project for alleviating the shortage of freshwater. It is necessary to notice that the water yield of the project is calculated to be $9.12 \mathrm{E}+06 \mathrm{~m}^{3}$, which could achieve the freshwater balance of the construction phase in the first year of operation. The comprehensive inventory and procedure of the embodied water accounting in this work are expected to provide useful references for rational allocation of water resources and optimal design for other desalination projects. 
23 Keywords: Embodied water, Seawater desalination, Water resources, Systems process analysis

\section{Introduction}

Demand for water has been increasing due to continuous rapid growth of population and economy, leading to the global problems of water resource shortage. This increasingly affects global economic development and ecological environment, even leading to conflicts among countries and regions. One of the optimal solutions for solving the worldwide water crisis is to apply seawater desalination technologies for obtaining new water resources and increasing the total supply of freshwater (Khawaji et al., 2008; Mezher et al., 2011; Qiblawey and Banat, 2008). The roles of water production and consumption conceptually embodied in the construction phase of a seawater desalination project are thus critical for the operation and water saving of the project (Drouiche et al., 2011; Tsiourtis, 2001).

Generally, seawater desalination is regarded as a process of obtaining freshwater from seawater by physical, chemical or physical-chemical methods, which can provide continuous freshwater guarantee for people's livelihood, economic development and ecological maintenance in water-deficient areas. According to the National Seawater Utilization Report (2016), more than 100 seawater desalination projects have been completed in China by the end of 2016, with a water production scale of 1.89 million tons per day, with the largest seawater desalination project scale of 200,000 tons per day. 
China is the site of the largest water shortage areas in the world, providing vast potential for the construction of seawater desalination projects. According to the progress of seawater desalination in recent years, much research focused on the economic cost accounting and evaluation of project investments (Blank, 2007; Dreizin, 2006; Eltawil et al., 2009; Fiorenza et al., 2003; Kim et al., 2013; Linares et al., 2016). Most of the existing literature paid attention to the relationship between the output of desalination projects and the unique local direct water demands, which contribute to the systematical comparison and construction of seawater desalination projects in general. There is however little research on the accounting and evaluation of freshwater costs in the construction phase of desalination projects, which still deserves further evaluation.

At present, there is relevant literature on indirect utilization of freshwater resources in the construction phase, which highlights the significance of indirect water use in the construction phase (Crawford and Pullen, 2011; Malça and Freire, 2006). Reasonable utilization of supply chains and whole water consumption to strengthen construction projects are effective options to fill this gap (Berger and Finkbeiner, 2010; Kotsovinos et al., 2011). In view of the rapidly increasing water consumption and shortage of water resources, the research on embodied water accounting is in progress (Berger et al., 2012; Chapagain and Hoekstra, 2007; Chen and Chen, 2012; Chen et al., 2012; Hoekstra et al., 2011; Jeswnai and Azapagic, 2011; Stoessel et al., 2012; Zhao et al., 2010).

Generally speaking, the accounting methods for a case project mainly involve 
two kinds of methods. The process analysis starts from tracking the input data to the output data in the life cycle of the project to account for the resource utilization and environmental impacts (Dixon et al., 2003; Proença and Ghisi, 2010; Wong and Mui, 2008). This analysis attempts to trace the resource utilization and environmental emissions of all the production processes, though it is hard to cover all the processes with the limited steps (Arpke and Hutzler, 2006; Cabeza et al., 2014; Emmerson et al., 1995). On the contrary, the input-output method reflects the relationships among different economies by adopting a top-down perspective, which is applicable to carrying out the accounting analysis for a particular department or region. This method has been generally applied at the macro-scale of resource utilization and environmental emissions (Velázquez, 2007; Xia et al., 2015, 2016; Yang et al., 2010), while it is unnecessary to assess the specific engineering assessment due to the uniqueness of an individual case (Hondo et al., 2002; Miller and Blair, 2009).

With the advantages of the above mentioned methods, a hybrid analysis was proposed by Bullard et al. (1978), taking into account the rationality and comprehensiveness of the assessment results (Kramer et al., 1999; Lenzen, 1999, 2002). Based on the above studies and derived from the systems ecology, Chen et al. (2011b) proposed the systems process analysis integrating the above mentioned methods and taking low-carbon buildings as an example for the pursuit of systems accounting evaluation (Chen et al., 2013; Han et al., 2015b). With the continuous improvement of the accounting method, it was further applied in the evaluation of ecological factors (energy consumption, environmental emissions and water usage) of 
construction, electricity and wetland projects (Chen et al., 2009; Han et al., 2013, 2014; Liu et al., 2016; Meng et al., 2013, 2014; Shao and Chen, 2013, 2016; Wu and Chen, 2017).

Generally, the seawater desalination plant is considered as a type of significant water production system with regard to its ability to deliver fresh water. Existing studies on resources accounting have contributed extensively to the related assessment work (Malça and Freire, 2006). With the emergence of literature on the analyses of the embodied water consumption of seawater desalination, particularly where the productivity assessments are deficient, a comprehensive evaluation of embodied water of seawater desalination and the productivity levels of the related projects is necessary.

In this context, a systematic analysis of embodied water assessments on seawater desalination is comprehensively performed with the systems process analysis. By quantifying the freshwater costs of the Huanghua Desalination Project in Hebei Province, the water production and consumption of the desalination project covering 5 sub-projects are systematically analyzed, and the construction phase is comprehensively assessed with the comparisons of different types of water use. With the detailed classification of the basic materials, the measures for rational allocation and utilization of water resources in the desalination projects are discussed. The rest of this paper is as follows. Section 2 provides a description of the methodological approach. Section 3 describes the overall results obtained, Section 4 provides further discussion, and Section 5 concludes. 


\section{Method and data sources}

Details of the systems process analysis, data sources and case description are presented below.

\subsection{Systems process analysis}

This study applies the systems process analysis combined with the process analysis and the input-output analysis to pursue a systems accounting of the embodied method and enhance the data accuracy, the study was carried out according to the first-hand data based on the data list (Hebei Guohua Cangdong Power Generation Co.

Ltd, 2013). According to the specific requirements and specifications of the seawater

122 desalination project, all the involved items and economic costs are listed and 123 categorized into three types (equipment, materials and labor).

\subsubsection{Production industry and embodied water}

In the calculation of embodied water consumption, each project could be traced

126 back to its corresponding production industry through the supply chains. Denoted as

127 the total water use for final demand, embodied water intensity refers to the direct and

128 indirect water use per economic output in the production processes (Han et al., 2015b).

129 Based on the corresponding inventory and economic costs, the consumption of 130 embodied water can be calculated in each project. For the convenience of the 131 calculation, each sub-project with the same materials was merged into the same 132 economic industry as the overall economic costs in the whole engineering system. 


\subsubsection{Embodied water of sub-projects}

According to the material inputs and embodied intensity of each project and combining with the actual water usage of the case project (Liu et al., 2017), the multi-scale and multi-type embodied water usage of the case project can be 138 calculated:

$$
W_{\text {required }}=\sum_{i=1}^{n} W_{i}=\sum_{i=1}^{n}\left(\varepsilon_{i} \times I_{i}\right)
$$

140 where $I_{i}$ is the economic cost of the corresponding sector $i$ in the input list of the 141 seawater desalination project, $\varepsilon_{i}$ denotes the multi-type embodied intensity of sector $i$, 142 and $W_{i}$ is the embodied water use of sector $i$. By calculating the total consumption of 143 each sub-project, the whole project's embodied water in the supply chain can be 144 summed.

\subsubsection{Embodied water assessments of seawater desalination projects}

147 Based on the above process, the net water production $W_{\text {procduction }}$ in this work is to 148 assess the impact of water production on the supply of local water resources, which 149 could be obtained as:

$$
W_{\text {production }}=W_{\text {desalted }}-W_{\text {required }}
$$

151 Since seawater desalination is devised as a technology for alleviating the 152 shortage of freshwater resources, the investment rate $R_{\text {investment }}$ of the seawater 153 desalination project can be measured by the seawater desalted in embodied water 154 investment:

$$
R_{\text {investment }}=W_{\text {required }} / W_{\text {desalted }}
$$


Furthermore, in order to reflect the freshwater production capacity of the case project, the productivity level $L_{\text {productiviy }}$ of the desalination project can be calculated as follows:

$$
L_{\text {productivity }}=\left(W_{\text {desalted }}-W_{\text {required }}\right) / W_{\text {required }}
$$

Detailed equations and symbols are presented in Table 1 for reference.

Table 1

Assessments of the seawater desalination system.

\begin{tabular}{|c|c|c|c|}
\hline Index & Content & Definition & Equation \\
\hline$W_{\text {desalted }}$ & Desalted water & Total water desalted through the desalination project & \\
\hline$W_{\text {required }}$ & Embodied water & The embodied water required to desalted water & \\
\hline$W_{\text {production }}$ & Water production & $\begin{array}{l}\text { The desalted water volume after removing the } \\
\text { freshwater costs }\end{array}$ & $W_{\text {desalted }}-W_{\text {required }}$ \\
\hline$R_{\text {investment }}$ & Investment rate & $\begin{array}{l}\text { The embodied water requirement to the desalted } \\
\text { seawater volume }\end{array}$ & $W_{\text {required }} / W_{\text {desalted }}$ \\
\hline$L_{\text {productivity }}$ & Productivity level & $\begin{array}{l}\text { The net water production in embodied water } \\
\text { requirement }\end{array}$ & $\begin{array}{l}\left(W_{\text {desalted }}-W_{\text {required }}\right) / \\
W_{\text {required }}\end{array}$ \\
\hline
\end{tabular}

\subsection{Case description and data sources}

\subsubsection{Case description}

The LT-MED third-phase project located in Hebei Province was developed in 2013 by the Huanghua Power Plant, which processes 25.00 thousand tons/day of fresh water and chosen as the study case in this work. With the third phase project, the capacity of daily water production of the Huanghua Power Plant increased from 32.50 to 57.50 thousand tons, and the capacity of the external water supply increased from 18.80 to 40.00 thousand tons, ranking it as first place in China. According to the calculation of the operating phase of 20 years, the total amount of freshwater produced is $1.83 \mathrm{E}+08 \mathrm{~m}^{3}$. 
The distillation technology in this project is regarded as one of the most widely

175

176

177

178

179

180

182

used desalination technologies, which has been widely used in various seawater desalination projects. Distillation desalination technology includes multi stage flash distillation (MSF), multi effect distillation (MED) and mechanical vapor compression (MVC). The low temperature multi effect distillation (LT-MED) was developed in 1980s, with the process flow diagram shown in Fig. 1. This technology shows its advantages in high-quality desalted water, simple equipment structure, no limit by the original seawater concentration and no special requirements for pretreatment. The case project co-produces both electricity and desalinated water, which is an ideal option for the construction of large-scale desalination plants.

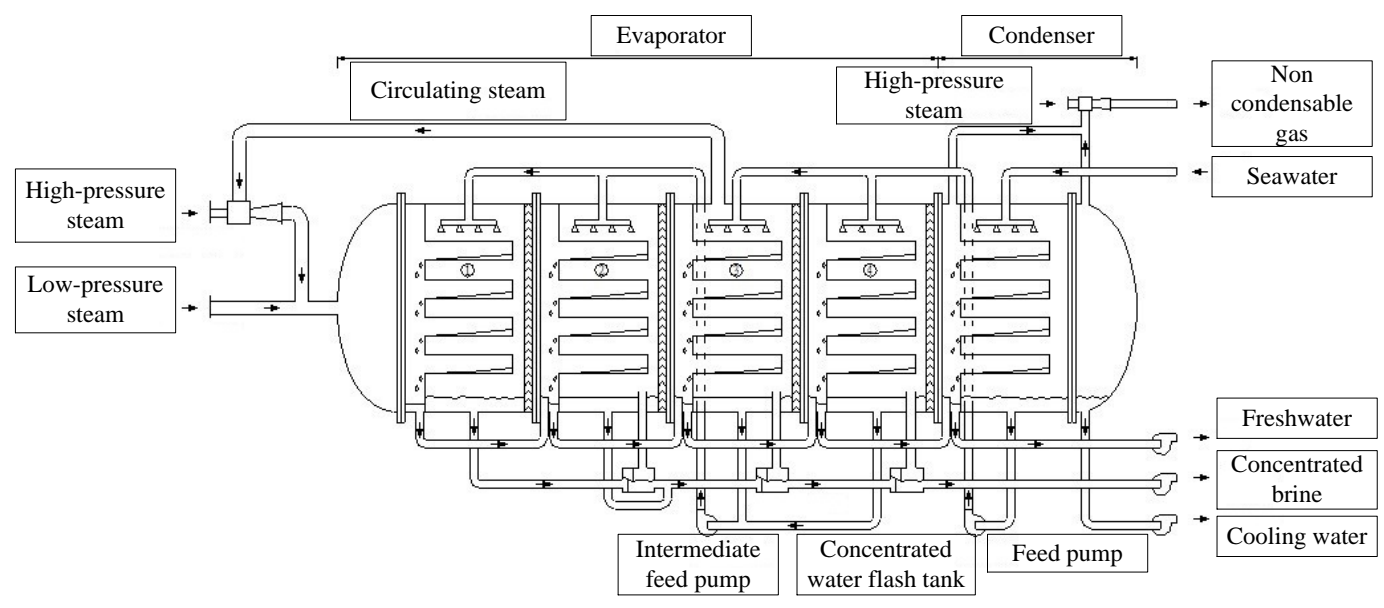

Fig. 1. The flow diagram of the case seawater desalination project.

As shown in Table 2, the construction phase of seawater desalination project can be further divided into three major projects (construction engineering, installation engineering, and other services), in which the installation engineering can be divided into three sub-projects (technology system engineering, electrical system engineering, 
191 and thermal control system engineering). Details are given in Appendix A and B, and

192 the full names and abbreviations of the sub-projects are listed in Table 2 for reference.

\section{Table 2}

194 The full names and abbreviations of the sub-projects.

\begin{tabular}{llll}
\hline No. & Projects & Sub-projects & Abbrev. \\
\hline 1 & Construction engineering & & Construction engineering \\
2 & Installation engineering & & Installation engineering \\
3 & & Technology system engineering & Technology system \\
4 & & Electrical system engineering & Electrical system \\
5 & & Thermal control system engineering & Thermal control system \\
6 & Other services & & Other services \\
\hline
\end{tabular}

195

\subsubsection{Data sources}

The systems assessments of embodied water for seawater desalination projects require an appropriate embodied water intensity inventory database, which covers all economic products corresponding to the production industry. For different types of projects, the embodied water intensity database has been derived based on the systems input-output analysis (Chen et al., 2011a, c, 2013; Chen and Han, 2015a, b; Han et al., 2015a, 2018; Li and Han, 2018). Based on the data of Hebei Province's input-output table and the systems analysis, the embodied water intensity inventory of Hebei Province in 2012 has been obtained, which provided the most accurate and detailed data for Hebei Province (Liu et al., 2017; Han et al., 2017). The unit of the database is cubic meters/million CNY, and the full names and abbreviations of the relevant input-output sectors are presented in Table 3 for reference.

\section{Table 3}

The full names and abbreviations of the relevant input-output departments. 


\section{Results}

\subsection{Embodied water of sub-projects in seawater desalination}

Fig. 2 presents the consumption structure of the construction phase. To conduct a

214 detailed analysis, the detailed results of the embodied water of 5 sub-projects in the

215 construction phase of the case project are presented below. Detailed data can be

216 referred in Appendix C.

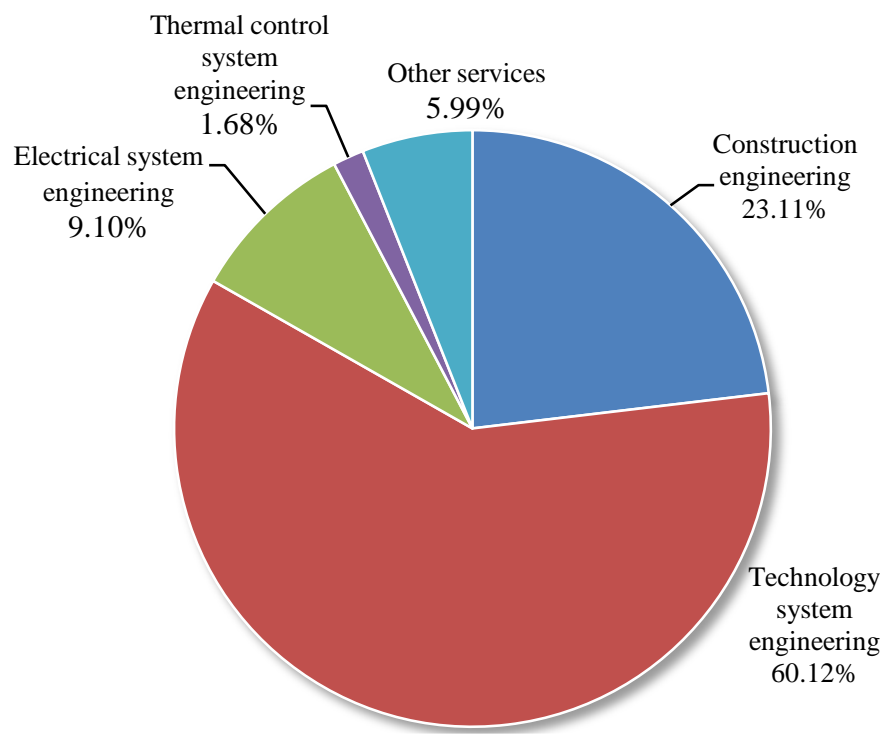

Fig. 2. Embodied water structure in the construction phase. 
As the fundamental sub-project, the embodied water consumption of the

221 construction engineering is $2.09 \mathrm{E}+06 \mathrm{~m}^{3}$, accounting for $23.11 \%$ in the construction

222 phase of the case project. Specific to each component, general civil engineering

223 projects account for nearly $40 \%$ of the total embodied water of construction 224 engineering, followed by foundation treatment $(15.52 \%)$ and pool $(10.43 \%)$ as 225 shown in Fig. 3.

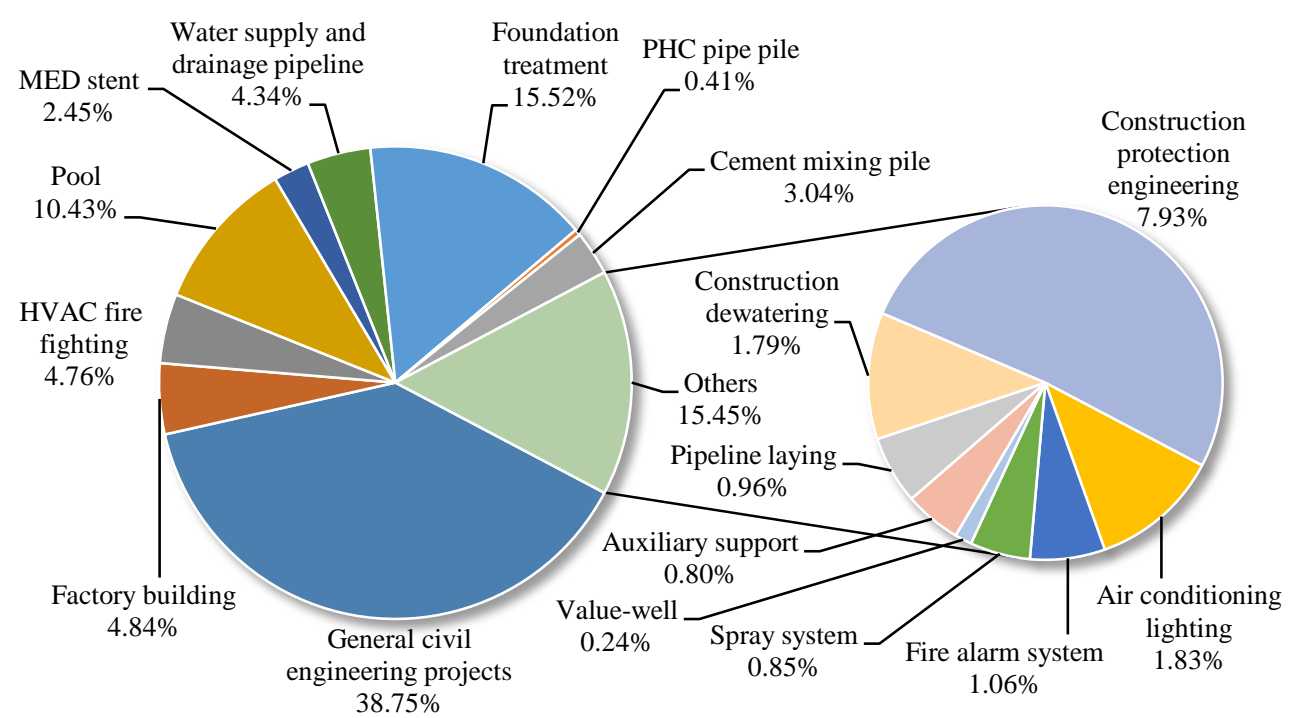

Fig. 3. Embodied water structure of construction engineering.

Technology system engineering is the largest embodied water consumption and system device of the seawater desalination occupy large proportions as well, project in the construction phase, with the total amount reaching $5.42 \mathrm{E}+06 \mathrm{~m}^{3}$. Water pump and frequency converter are the main components $\left(3.66 \mathrm{E}+06 \mathrm{~m}^{3}\right)$, accounting 
235 accessories and materials account for about $10 \%$, in which other installation materials 236 account for the largest proportion in this component.

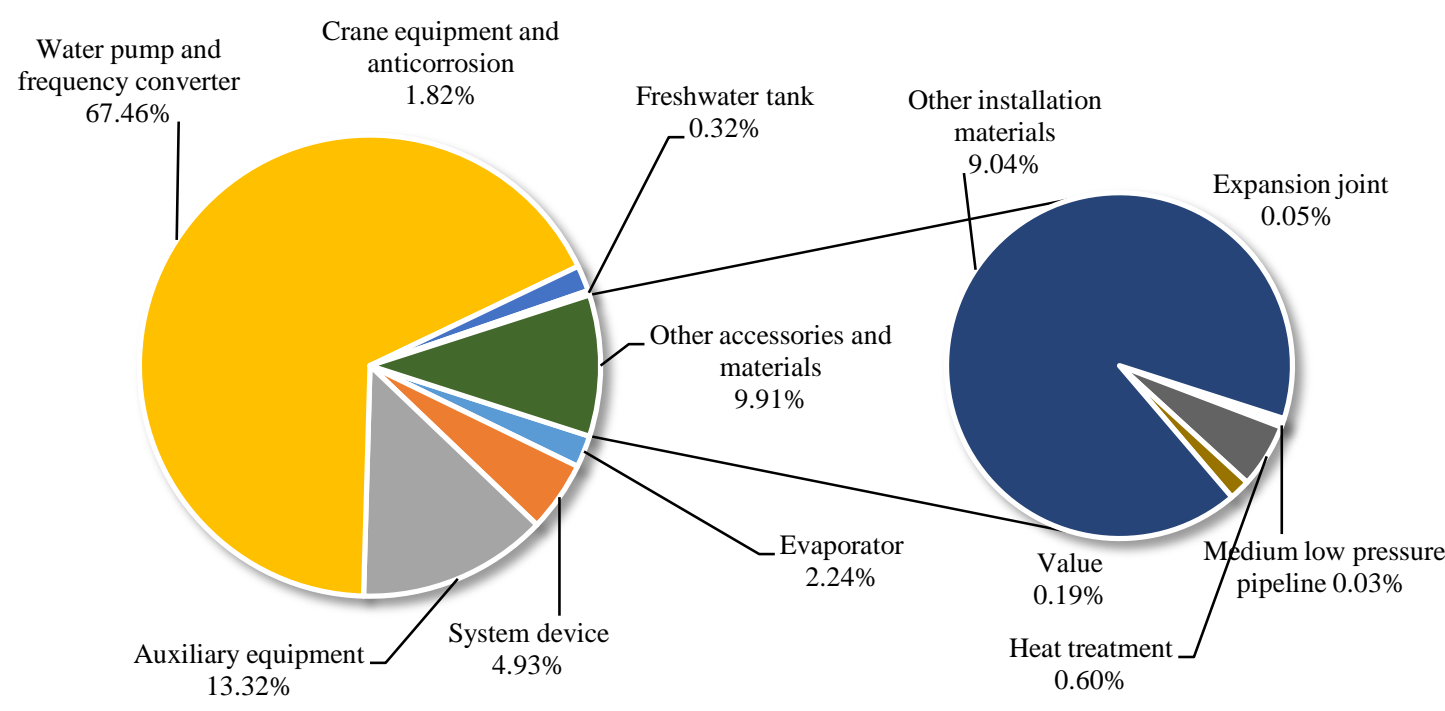

Fig. 4. Embodied water structure of technology system engineering.

241 supply equipment, auxiliary materials and facilities and equipment installation. The

242 embodied water consumption of $6 \mathrm{KV}$ station-service power supply equipment is $2432.43 \mathrm{E}+05 \mathrm{~m}^{3}$, accounting for nearly $30 \%$ of the total in the electrical system 244 engineering. Besides, the embodied water consumption of the cable bridge support is $2451.60 \mathrm{E}+05 \mathrm{~m}^{3}$, accounting for nearly $20 \%$ of the total in this sub-project. Other 246 auxiliary materials and facilities account for the largest proportion, reaching 247 approximately $37.47 \%$ as shown in Fig. 5. 


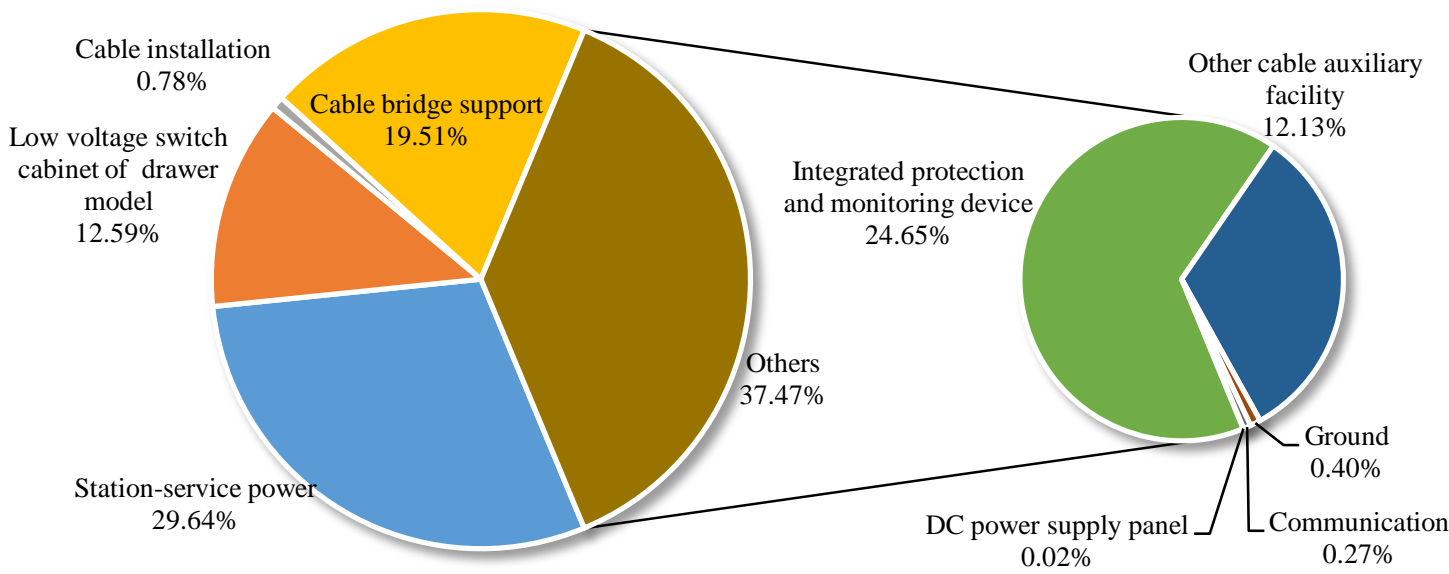

Fig. 5. Embodied water structure of electrical system engineering.

The thermal control system is mainly composed of the PLC device, servers, main

252 instruments, control equipment, cables, auxiliary facilities and other installation

253 materials. Fig. 6 depicts the detailed structures of the embodied water consumption of

254 the thermal system engineering. The PLC control system is the core component of this

255 sub-engineering, whose consumption is $1.12 \mathrm{E}+05 \mathrm{~m}^{3}$, with $73.87 \%$ of the total in this

256 project. The system server and cables and ancillary facilities also account for large

257 shares in the sub-project, with the proportions of $12.65 \%$ and $7.78 \%$ respectively as 258 shown in Fig. 6. 


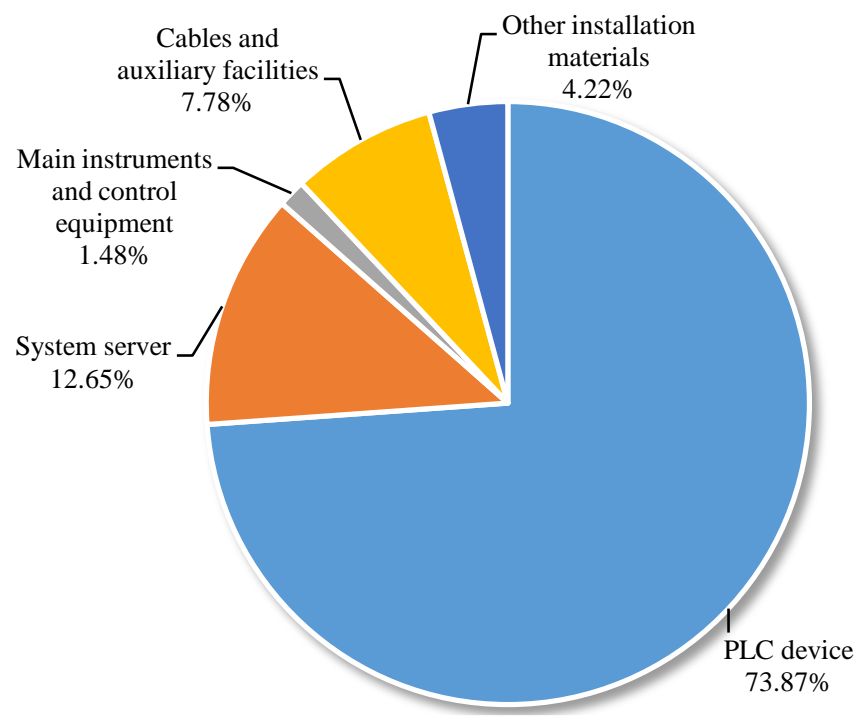

Fig. 6. Embodied water structure of thermal control system engineering.

Other services include the management and technical services of the project

263 construction, the costs of system commissioning and trial operation and other 264 expenses. The technical services of the project construction are the largest embodied 265 water consumption component in this sub-project, whose consumption is $3.05 \mathrm{E}+05$ $266 \mathrm{~m}^{3}$, accounting for $56.46 \%$ of the total. Besides, the embodied water consumption of 267 the management in the project construction accounts for about $9.04 \%$ as well, as 268 shown in Fig. 7. 
Technical services of the project construction $56.46 \%$

Fig. 7. Embodied water structure of other services.

\subsection{Multi-types of embodied water in the construction phase}

The embodied water intensity database applied in this study is composed of four

274 types of water use, namely agricultural production, industrial production, household

275 use and biological protection. With the obtained database, the four proportions of

276 embodied water consumption in the construction phase are calculated as $3.54 \%$,

$27754.22 \%, 41.80 \%$ and $0.43 \%$, respectively. Among them, the industrial production and

278 household use account for the large proportions of the total. Detailed data of five

279 sub-projects are listed in Table 4.

280 Table 4

281 Embodied water consumption of sub-projects in construction phase.

\begin{tabular}{|c|c|c|c|c|c|}
\hline Sub-projects & $\begin{array}{l}\text { Agricultural } \\
\text { production }\end{array}$ & $\begin{array}{l}\text { Industrial } \\
\text { production }\end{array}$ & $\begin{array}{c}\text { Household } \\
\text { use }\end{array}$ & $\begin{array}{l}\text { Biological } \\
\text { protection }\end{array}$ & $\begin{array}{c}\text { Total } \\
\text { consumption }\end{array}$ \\
\hline Construction engineering & $5.33 \mathrm{E}+04 \mathrm{~m}^{3}$ & $1.13 \mathrm{E}+06 \mathrm{~m}^{3}$ & $8.98 \mathrm{E}+05 \mathrm{~m}^{3}$ & $8.53 \mathrm{E}+03 \mathrm{~m}^{3}$ & $2.09 \mathrm{E}+06 \mathrm{~m}^{3}$ \\
\hline
\end{tabular}




\begin{tabular}{c|ccccc}
\hline $\begin{array}{r}\text { Types of } \\
\text { water use }\end{array}$ & $\begin{array}{c}\text { Agricultural } \\
\text { production }\end{array}$ & $\begin{array}{c}\text { Industrial } \\
\text { production }\end{array}$ & $\begin{array}{c}\text { Household } \\
\text { use }\end{array}$ & $\begin{array}{c}\text { Biological } \\
\text { protection }\end{array}$ & $\begin{array}{c}\text { Total } \\
\text { consumption }\end{array}$ \\
\hline Install engineering & $2.44 \mathrm{E}+05 \mathrm{~m}^{3}$ & $3.48 \mathrm{E}+06 \mathrm{~m}^{3}$ & $2.64 \mathrm{E}+06 \mathrm{~m}^{3}$ & $2.81 \mathrm{E}+04 \mathrm{~m}^{3}$ & $6.39 \mathrm{E}+06 \mathrm{~m}^{3}$ \\
Technology system & $2.06 \mathrm{E}+05 \mathrm{~m}^{3}$ & $2.95 \mathrm{E}+06 \mathrm{~m}^{3}$ & $2.24 \mathrm{E}+06 \mathrm{~m}^{3}$ & $2.40 \mathrm{E}+04 \mathrm{~m}^{3}$ & $5.42 \mathrm{E}+06 \mathrm{~m}^{3}$ \\
Electrical system & $2.79 \mathrm{E}+04 \mathrm{~m}^{3}$ & $4.50 \mathrm{E}+05 \mathrm{~m}^{3}$ & $3.39 \mathrm{E}+05 \mathrm{~m}^{3}$ & $3.38 \mathrm{E}+03 \mathrm{~m}^{3}$ & $8.20 \mathrm{E}+05 \mathrm{~m}^{3}$ \\
Thermal control system & $1.04 \mathrm{E}+04 \mathrm{~m}^{3}$ & $8.06 \mathrm{E}+04 \mathrm{~m}^{3}$ & $5.95 \mathrm{E}+04 \mathrm{~m}^{3}$ & $7.34 \mathrm{E}+02 \mathrm{~m}^{3}$ & $1.51 \mathrm{E}+05 \mathrm{~m}^{3}$ \\
& & & & & \\
Other services & $2.14 \mathrm{E}+04 \mathrm{~m}^{3}$ & $2.87 \mathrm{E}+05 \mathrm{~m}^{3}$ & $2.30 \mathrm{E}+05 \mathrm{~m}^{3}$ & $2.45 \mathrm{E}+03 \mathrm{~m}^{3}$ & $5.40 \mathrm{E}+05 \mathrm{~m}^{3}$ \\
\hline \multirow{2}{*}{ Total consumption } & & & & & \\
\hline
\end{tabular}

283 Fig. 8 further depicts the constituents of embodied water of 5 sub-projects in the

284 construction phase. The technology system engineering is regarded as the sub-project

285 with the largest embodied water consumption in the construction phase. The

286 proportions of the four types of embodied water in the sub-project are $3.83 \%, 54.42 \%$,

$28741.32 \%$ and $0.44 \%$, corresponding to agricultural production, industrial production,

288 household use and biological protection respectively. 
Fig. 8. The multi-type embodied water of 5 sub-projects in the construction phase.

292 Meanwhile, Fig. 9 shows the constituents of four types of embodied water of 3

293 projects in the construction phase, among which the installation engineering is the

294 largest embodied water consumption project. With the detailed results of the 3

295 projects, the proportions in the installation engineering regarding agricultural

296 production, industrial production, household use and biological protection are $3.68 \%$,

$29754.37 \%, 41.52 \%$ and $0.43 \%$ respectively. 


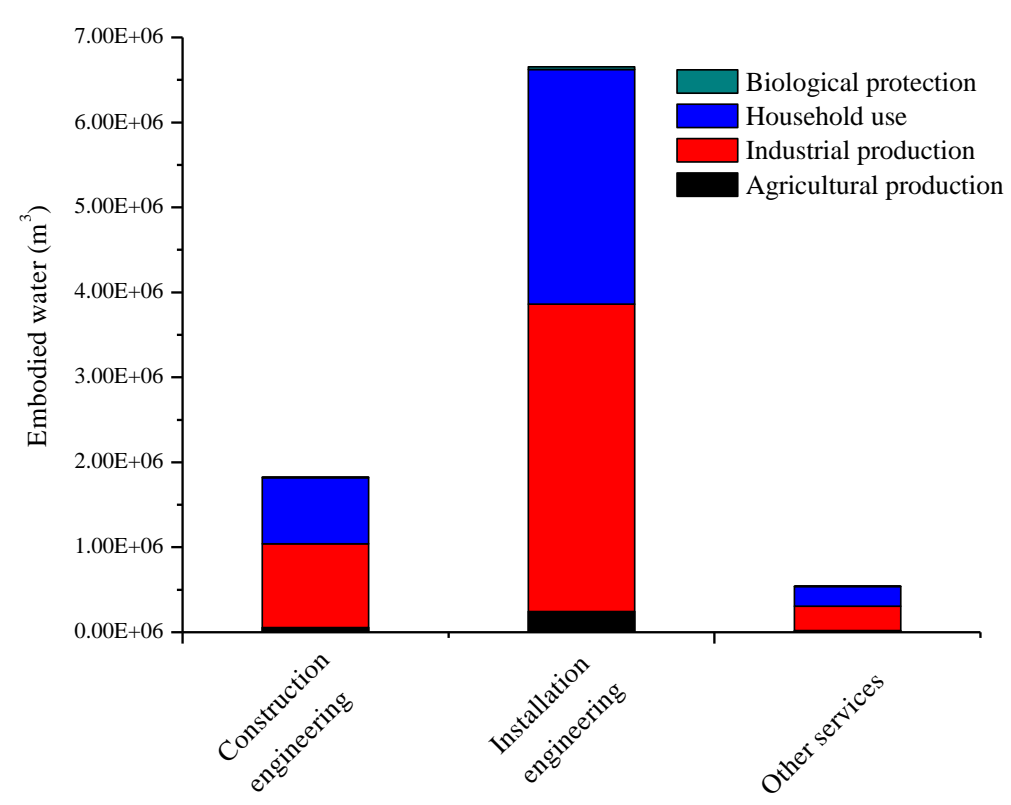

298

299

300

301

302

303

Fig. 9. The multi-type embodied water of 3 sub-projects in the construction phase.

The above results present that technology system engineering is the largest embodied water sub-project in the construction phase when it is divided into 5 sub-projects, and installation engineering is the largest embodied water consumption project in the construction phase when divided into 3 projects. The proportion of the four types of water use of embodied water in these two projects is close to the proportion of the total amount of embodied water. Among all types of water use, the proportions of industrial water and household water are with large quantities. As for the other sub-projects in this phase, agricultural and biological water are less involved in the construction phase of the seawater desalination project. Detailed data can be referred in Appendix C.

\section{Discussion}

The case project in Huanghua, Cangzhou covers an area of about 33 thousand 
314 square meters, and the direct water consumption $W_{\text {direct }}$ is estimated to be $1.60 \mathrm{E}+05$

$315 \mathrm{~m}^{3}$. Based on the results, the embodied water consumption $W_{\text {required }}$ in the construction 316 phase of the case project is calculated as $9.02 \mathrm{E}+06 \mathrm{~m}^{3}$. From the results, the amount 317 of embodied water consumption is 56 times higher than the direct water consumption 318 when considering the indirect water consumption in this phase. The total freshwater 319 production $W_{\text {desalted }}$ in operation life cycle is $1.83 \mathrm{E}+08 \mathrm{~m}^{3}$, which is 20.29 times of the 320 total freshwater consumption in the construction phase. After removing the freshwater 321 costs in the construction phase, the net water production $W_{\text {production }}$ can reach $1.74 \mathrm{E}+08$ $322 \mathrm{~m}^{3}$, which means the average net water production per year $w_{\text {production }}$ is $8.70 \mathrm{E}+06 \mathrm{~m}^{3}$, 323 almost equivalent to the local average water supply in 20 years.

324 Among all the sub-projects, the embodied water consumption in the technology 325 system engineering represents the largest component, accounting for $60.12 \%$ of the 326 total embodied water consumption. Followed is construction engineering, accounting 327 for $23.11 \%$ of the total. Taking the installation project (including technology system 328 engineering, electrical system engineering, and thermal control system engineering) 329 as a whole, the embodied water consumption of installation engineering in the 330 construction phase is much larger than in the other sub-projects, accounting for $70.90 \%$ 331 of the total.

332 Overall, the investment rate $R_{\text {investment }}$ of the case project is calculated as 20:1, 333 and the productivity level $L_{\text {productivity }}$ of the case project is calculated as 19.29 , far 334 greater than 1, indicating that desalination water production is much higher than the embodied water consumption in the construction phase. In the first year of operation, 
the water yield of the project is calculated to be $9.12 \mathrm{E}+06 \mathrm{~m}^{3}$, which could achieve the freshwater balance in the construction phase. According to the statistics of Cangzhou Statistical Bureau (2014) and Hebei Water Resources Bulletin (2013), there were 1993 industrial enterprises above the designated size, and the total annual industrial water demand per year in Cangzhou area is $2.68 \mathrm{E}+08 \mathrm{~m}^{3}$. With the design standard of the case project, it is expected to meet the water demands of 8 enterprises in Cangzhou New Area. With the supply ability of the desalination project, the total industrial water demands of 8 enterprises in Cangzhou New Area is about 1.08E+06 $\mathrm{m}^{3}$, which accounts for $12.4 \%$ of the total annual net water output of the case project.

After removing the industrial water and household water used in the power plant where the project is located, there is still about $85 \%$ of the net water output available for other enterprises, greatly alleviating the local water demands at the local economy. Detailed indicators are listed in Table 5 for reference.

\section{Table 5}

Basic indicators of the case project.

\begin{tabular}{llll}
\hline Index & Data & Index & Data \\
\hline$W_{\text {direct }}$ & $1.60 \mathrm{E}+05 \mathrm{~m}^{3}$ & $L_{\text {productivity }}$ & 19.29 \\
$W_{\text {required }}$ & $9.02 \mathrm{E}+06 \mathrm{~m}^{3}$ & $R_{\text {investment }}$ & $20: 1$ \\
$W_{\text {desalted }}$ & $1.83 \mathrm{E}+08 \mathrm{~m}^{3}$ & $Y_{\text {investment }}$ & $1^{\text {st }}$ year \\
$W_{\text {production }}$ & $1.74 \mathrm{E}+08 \mathrm{~m}^{3}$ & $N_{\text {supply }}$ & 8 enterprises \\
\hline
\end{tabular}

Fig. 10 further summarized the different levels of freshwater cost materials in the basic seawater desalination project based on the above results. Five levels of freshwater costs are classified according to the magnitude of embodied water consumption. Generally speaking, the inputs in the construction phase of seawater 
356 desalination project include general civil engineering projects, foundation treatment,

357 seawater desalination pump and frequency converter, seawater desalination system

358 and auxiliary equipment, technical services of seawater desalination project, other

359 installation materials and 6KV station-service power supply equipment. From Fig. 10,

360 the general civil engineering projects, foundation treatment, seawater desalination

361 pump and frequency converter, seawater desalination system and auxiliary equipment,

362 technical services of seawater desalination project, other installation materials are

363 classified in the higher level of freshwater costs, which mainly concentrate in the

364 technology system engineering and construction engineering. In addition, components

365 including evaporator, water supply and drainage pipeline, PLC device, cable bridge

366 and other cable auxiliary facilities belong to the lower level of freshwater costs, which

367 are always regarded as the indispensable components for desalination projects as well.

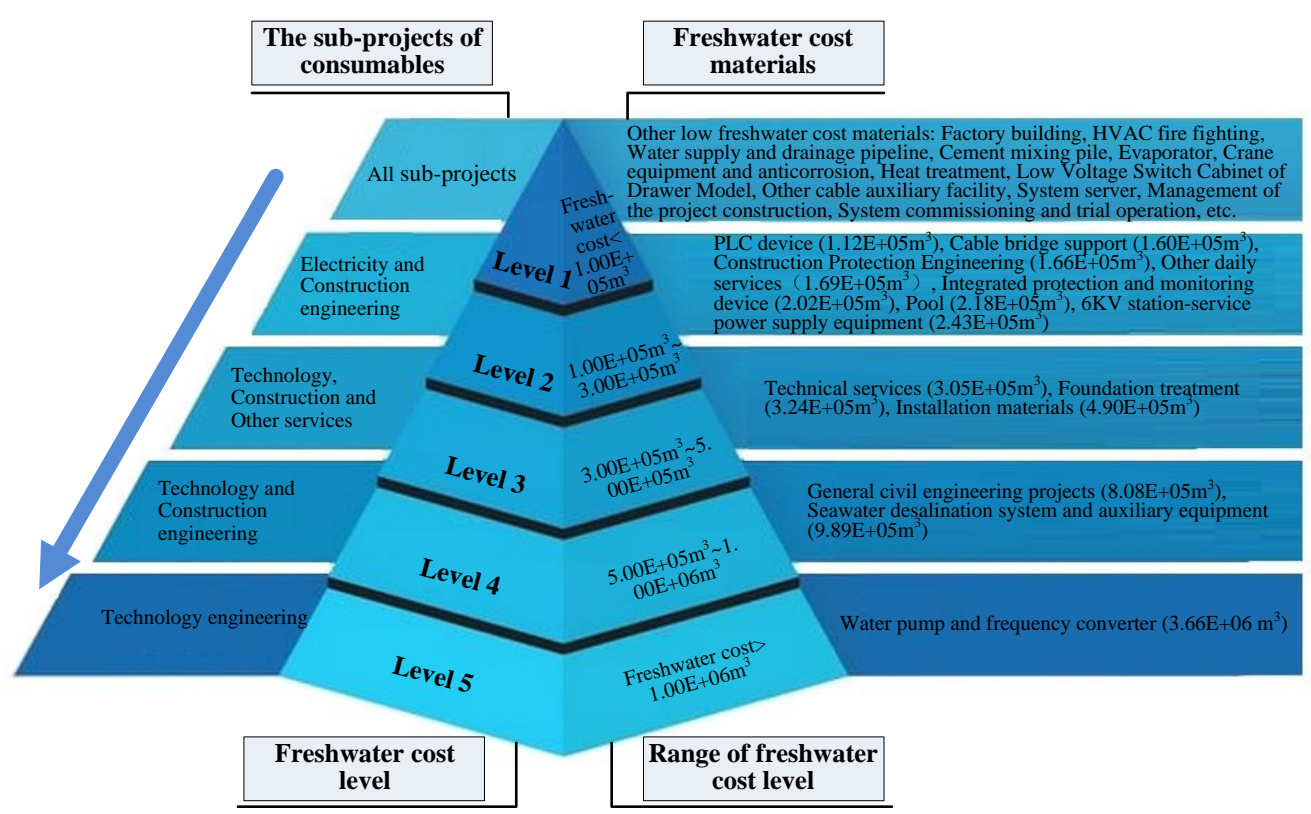

Fig. 10. The pyramid model of freshwater cost levels. 
371 In recent years, the seawater desalination technology has made great progresses

372 around the world. As one of the most water shortage countries in the world, China has

373 huge requirements for the desalination construction to ease the water crisis. For a

374 clear presentation, the distribution of key water shortage areas and the distribution

375 scales of existing desalination in China are depicted in Fig. 11. According to the

376 National Seawater Utilization Report (2016), more than 100 seawater desalination

377 projects have been completed in China, with a water production scale of nearly 2

378 million tons per day. According to the 13th Five-Year Plan for the Utilization of

379 Seawater in China (2016), the total scale of seawater desalination in China will reach

380 more than 2.20 million tons per day by 2020 , which means most of the coastal areas

381 would vigorously conduct the construction and upgrading of seawater desalination

382 projects.

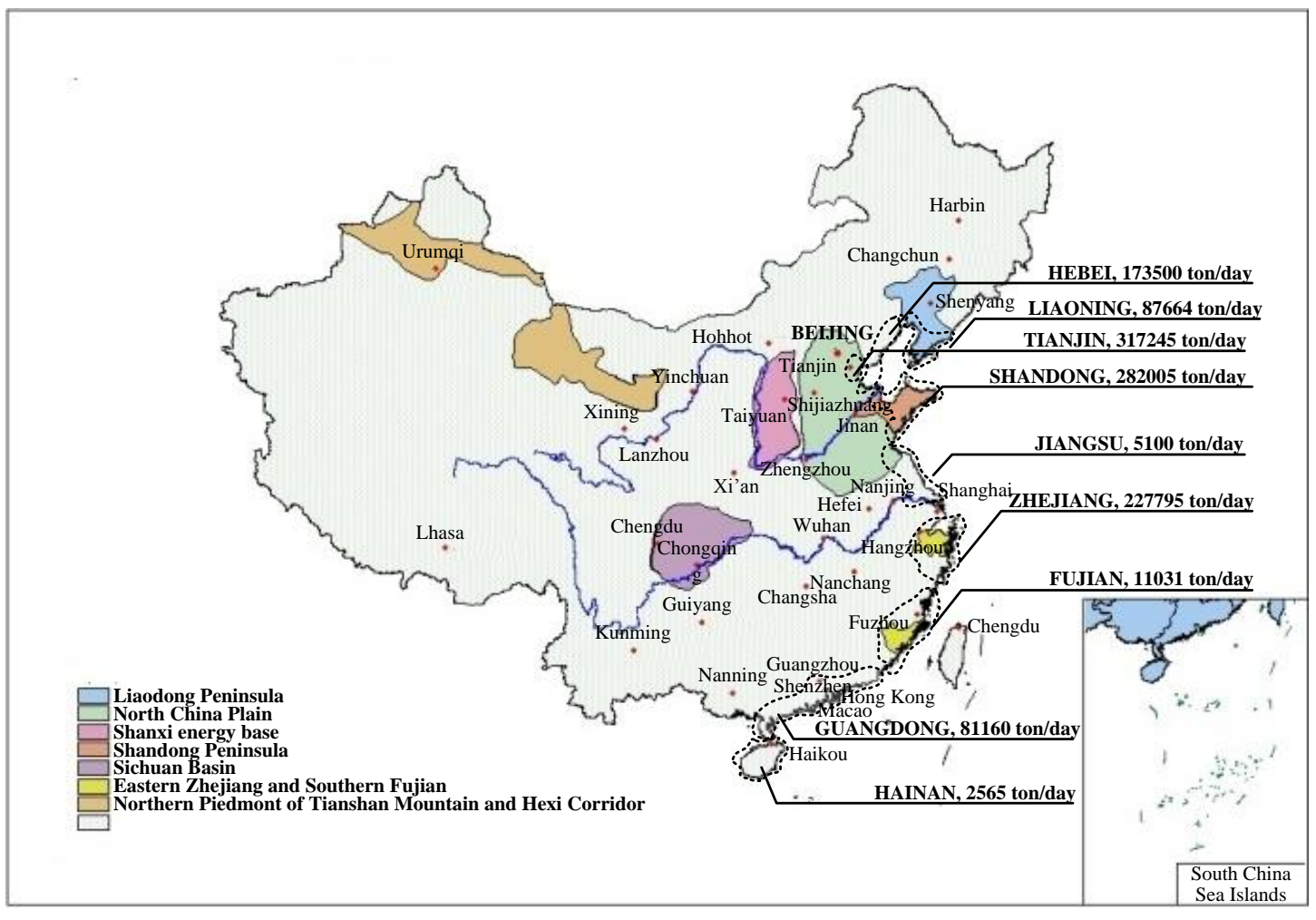


Fig. 11. Water shortage areas and seawater desalination distribution in China.

Besides, the different desalination projects in the previous studies among the

world are also compared in Table 6. The economic investments of these projects were

always evaluated; however few studies focused on the freshwater cost evaluation on

the desalination projects. Generally, the economic costs are highly related to

production capacity, while the production capacity of the case project almost ranks in

391 the first place among these projects. With the obtained item inputs from the Huanghua

392 Power Plant, the freshwater costs are systematically assessed with detailed material

393 evaluation. On the one hand, this assessment could provide fundamental references

394 for plant design improving and engineering operation optimizing from the freshwater

395 cost perspective. On the other hand, it can effectively avoid the inefficient water use

396 and achieve the reasonable water allocation for regional collaborated development.

\section{$397 \quad$ Table 6}

398 Comparisons of seawater desalination plants.

\begin{tabular}{|c|c|c|c|c|c|}
\hline Location & Country & Plant capacity & Reference & $\begin{array}{c}\text { Suitable RE-desalination } \\
\text { combination } \\
\end{array}$ & $\begin{array}{c}\text { Unit } \\
\text { product }\end{array}$ \\
\hline--- & --- & $1500 \mathrm{~m}^{3} /$ day & Nafey et al., 2008 & Solar thermal-MEE-MVC & $1.24 \$ / \mathrm{m}^{3}$ \\
\hline $\begin{array}{c}\text { Near Dead } \\
\text { Sea }\end{array}$ & Israel & $3000 \mathrm{~m}^{3} /$ day & $\begin{array}{c}\text { European Commission, } \\
1998\end{array}$ & Solar thermal-MEB & --- \\
\hline Safat & Kuwait & $10 \mathrm{~m}^{3} /$ day & $\begin{array}{c}\text { European Commission, } \\
1998\end{array}$ & Solar thermal-MSF & --- \\
\hline Almeria & Spain & $72 \mathrm{~m}^{3} /$ day & Zarza, 1991 & Solar thermal-MED-TVC & --- \\
\hline $\begin{array}{l}\text { University } \\
\text { of Ancona }\end{array}$ & Italy & $30 \mathrm{~m}^{3} /$ day & $\begin{array}{c}\text { Caruso and Naviglio, } \\
1999\end{array}$ & Solar thermal-MEB & --- \\
\hline Ranau & Malaysia & $20000 \mathrm{~m}^{3} /$ day & $\begin{array}{l}\text { Chiam and Sarbatly, } \\
2013\end{array}$ & Geothermal-VMD & $0.50 \$ / \mathrm{m}^{3}$ \\
\hline
\end{tabular}


In order to improve the utilization of seawater desalination, it is necessary to

401 strengthen the supervision of high-level water consuming materials, optimize process

operation systems, and improve the investment rate and productivity level of the

403 desalination projects. Among the basic components, the desalination materials

404 including desalination pumps and frequency converter, desalination systems and

405 auxiliary equipment, desalination project technical services deserve further attention.

Besides, the construction of seawater desalination project requires a systematic

407 accounting system for life cycle measurement for water-saving cooperation and

408 reasonable allocation. Overall, there are still huge potentials to improve the

409 optimization of seawater desalination from the upstream and downstream of the

410 supply chains, which could have positive effects on the productivity of seawater

411 desalination plants and provide necessary references for water saving strategies.

\section{5. Conclusion}

This study focused on Hebei Guohua Huanghua Power Plant's desalination

415 project and assessed the freshwater costs to obtain detailed embodied water inventory 
416 of the desalination materials in the construction phase. The water production and

417 consumption of the desalination project covering 5 sub-projects are systematically 418 analyzed, and the construction phase is comprehensively assessed with the 419 comparisons of different types of water use. This work applies the systems accounting 420 for the freshwater cost assessments of a seawater desalination project from the 421 embodied perspective for the first time, laying a solid foundation for systems water 422 accounting of the Huanghua power plant as well as other possible projects in water 423 shortage areas.

424 Overall, the total embodied water consumption $W_{\text {required }}$ in construction phase is $4259.02 \mathrm{E}+06 \mathrm{~m}^{3}$, which is 56 times higher than the direct water consumption $W_{\text {direct }}$ in 426 the phase. The total water production $W_{\text {production }}$ is expected to be $1.83 \mathrm{E}+08 \mathrm{~m}^{3}$ in the 42720 year life cycle and the net water production per year $w_{\text {production }}$ can reach $8.70 \mathrm{E}+06$ $428 \mathrm{~m}^{3}$. The embodied water consumption of technology system engineering is $5.42 \mathrm{E}+06$ $429 \mathrm{~m}^{3}$, which is the highest among sub-projects. The seawater desalination productivity 430 level $L_{\text {productivity }}$ of the case project are 19.29, which represents the fact that it greatly 431 alleviates the shortage of freshwater resources and makes a certain contribution to the 432 water-saving strategy in China.

433 This work clearly provides a set of freshwater cost accounting and assesses the 434 desalination productivity of desalination projects. It is the first time to apply the 435 systems process analysis to the freshwater cost assessment of seawater desalination, 436 which fills the blank in the field of freshwater accounting and evaluation. Meanwhile, 437 the study conducts a system accounting on the construction of new seawater 
desalination projects and the management of freshwater operation of existing projects.

With the comprehensive inventory of the embodied water consumption, the detailed analyses in this work provide a detailed profile for the freshwater cost assessments of seawater desalination projects, presenting a great ability to alleviate the shortage of freshwater resources and to extend this research to other desalination projects.

\section{References}

Arpke, A., Hutzler, N., 2006. Domestic water use in the United States: A life-cycle approach. J. Ind. Ecol. 10, 169-184.

Berger, M., Finkbeiner, M., 2010. Water footprinting: How to address water use in life cycle assessment? Sustainability 2 (4), 919-944.

Berger, M., Warsen, J., Krinke, S., Bach, V., Finkbeiner, M., 2012. Water footprint of european cars: Potential impacts of water consumption along automobile life cycles. Environ. Sci. Technol. 46 (7), 4091-4099.

Blank J.E., Tusel G.F., Nisan S., 2007. The real cost of desalted water and how to reduce it further. Desalin. 205 (1), 298-311.

Bullard, C.W., Penner, P.S., Pilati, D.A., 1978. Net energy analysis: Handbook for combining process and input-output analysis. Resour. Energy 1, 267-313.

Cabeza, L.F., Rincón, L., Vilariño, V., Pérez, G., Castell, A., 2014. Life cycle assessment (LCA) and life cycle energy analysis (LCEA) of buildings and the building sector: A review. Renew. Sustain. Energy Rev. 29, 394-416.

Cangzhou Municipal People's Government, 2014. A government work report of Cangzhou City, http://www.cangzhou.gov.cn/zwbz/gzbg/260605.shtml (in Chinese).

Caruso, G., Naviglio, A., 1999. A desalination plant using solar heat as a heat supply, not affecting the environment with chemicals. Desalin. 122, 225-234.

Chapagain, A.K., Hoekstra, A.Y, 2007. The water footprint of coffee and tea consumption in the Netherlands. Ecol. Econ. 64 (1), 109-118.

Chen, B., Chen, G.Q., Hao, F.H., Yang, Z.F., 2009. The water resources assessment based on 
resource exergy for the mainstream Yellow River. Commun. Nonlinear Sci. Numer. Simul. 14, $331-344$.

Chen, G.Q., Chen, H., Chen, Z.M., Zhang, B., Shao, L., Guo, S., Zhou, S.Y., Jiang, M.M., $2011 b$. Low-carbon building assessment and multi-scale input-output analysis. Commun. Nonlinear Sci. Numer. Simul. 16, 583-595.

Chen, G.Q., Guo, S., Shao, L., Li, J.S., Chen, Z.M., 2013. Three-scale input-output modeling for urban economy: Carbon emission by Beijing 2007. Commun. Nonlinear Sci. Numer. Simul. 18, 2493-2506.

Chen, G.Q., Han, M.Y., 2015a. Global supply chain of arable land use: Production-Based and consumption-based trade imbalance. Land Use Policy 49, 118-130.

Chen, G.Q., Han, M.Y., 2015b. Virtual land use change in China 2002-2010: Internal transition and trade imbalance. Land Use Policy 47, 55-65.

Chen, G.Q., Shao, L., Chen, Z.M., Li, Z., Zhang, B., Chen, H., Wu, Z., 2011a. Low-carbon assessment for ecological wastewater treatment by a constructed wetland in Beijing. Ecol. Eng. $37,622-628$.

Chen, G.Q., Yang, Q., Zhao, Y.H., 2011c. Renewability of wind power in China: A case study of nonrenewable energy cost and greenhouse gas emission by a plant in Guangxi. Renew. Sustain. Energy Rev. 15, 2322-2329.

Chen, Z.M., Chen, G.Q., 2012. Virtual water accounting for the globalized world economy: National water footprint and international virtual water trade. Ecol. Indic. 28, 142-149.

Chen, Z.M., Chen, G.Q., Xia, X.H., Xu, S.Y., 2012. Global network of embodied water flow by systems input-output simulation. Front. Earth Sci. 6 (3), 331-344.

Chiam, C.K., Sarbatly, S., 2013. Vacuum membrane distillation processes for aqueous solution treatment-A review. Chem. Eng. Process. 74, 27-54.

Crawford, R.H., Pullen, S., 2011. Life cycle water analysis of a residential building and its occupants. Build. Res. Inf. 39, 589-602.

Dehmas, D.A., Kherba, N., Hacene, F.B., Merzouk, N.K., Merzouk, M., Mahmoudi, H., Goosen, M.F.A., 2011. On the use of wind energy to power reverse osmosis desalination plant: A case study from Ténès (Algeria). Renew. Sustain. Energy Rev. 15, 956-963.

Department of Water Resources of Hebei Province, 2018. Hebei Water Resources Bulletin 2013, 
http://www.hebwater.gov.cn/a/2018/03/02/2018030221903.html (in Chinese).

Dixon, A., Simon, M., Burkitt, T., 2003. Assessing the environmental impact of two options for small-scale wastewater treatment: Comparing a reedbed and an aerated biological filter using a life cycle approach. Ecol. Eng. 20 (4), 297-308.

Dreizin Y., 2006. Ashkelon seawater desalination project — off-taker's self costs, supplied water costs, total costs and benefits. Desalin. 190 (1), 104-116.

Drouiche, N., Ghaffour, N., Naceur, M.W., Mahmoudi, H., Ouslimane, T., 2011. Reasons for the fast growing seawater desalination capacity in Algeria. Water Resour. Manag. 25, 2743-2754.

Eltawil, M.A., Zhao, Z.M., Yuan, L.Q., 2009. A review of renewable energy technologies integrated with desalination systems. Renew. Sustain. Energy Rev. 13, 2245-2262.

Emmerson, R.H.C., Morse, G.K., Lester, J.N., Edge, D.R, 1995. The life-cycle analysis of small-scale sewage-treatment processes. Water Environ. 9 (3), 317-325.

Fiorenza, G., Sharma, V.K., Braccio, G., 2003. Techno-economic evaluation of a solar powered water desalination plant. Energy Convers. Manage. 44 (14), 2217-2240.

Han, M.Y., Chen, G.Q., Li, Y.L., 2018. Global water transfers embodied in international trade: Tracking imbalanced and inefficient flows. J. Clean. Prod. 184, 50-64.

Han, M.Y., Chen, G.Q., Meng, J., Wu, X.D., Alsaedi, A., Ahmad, B., 2015b. Virtual water accounting for a building construction engineering project with nine sub-projects: a case in E-town, Beijing. J. Clean. Prod. 112, 4691-4700.

Han, M.Y., Chen, G.Q., Mustafa, M.T., Hayat, T., Shao, L., Li, J.S., Xia, X.H., Ji, X., $2015 a$. Embodied water for urban economy: A three-scale input-output analysis for Beijing 2010. Ecol. Model. 318, 19-25.

Han, M.Y., Chen, G.Q., Shao, L., Li, J.S., Alsaedi, A., Ahmad, B., Guo, S., Jiang, M.M., Ji, X., 2013. Embodied energy consumption of building construction engineering: Case study in E-town, Beijing. Energy Build. 64, 62-72.

Han, M.Y., Michael, D., Chen, G.Q., Liu, W.D., Li, Y.L., Liu, S.Y., 2017. Global water transfers embodied in Mainland China's foreign trade: Production- and consumption-based perspectives. J. Clean. Prod. 161, 188-199.

Han, M.Y., Shao, L., Li, J.S., Guo, S., Meng, J., Ahmad, B., Hayat, T., Alsaadi, F., Ji, X., Alsaedi, A., 2014. Emergy-based hybrid evaluation for commercial construction engineering: A case 
study in BDA. Ecol. Ind. 47, 179-188.

Hebei Guohua Cangdong Power Generation Co. Ltd, 2013. The Final Accounts for the 25 thousand tons desalination project (accessed 31 Dec 2013) (in Chinese).

Hoekstra, A.Y., Chapagain, A.K., Aldaya, M.M., Mekonnen, M.M, 2011. The Water Footprint Assessment Manual: Setting the Global Standard. Earthscan, Washington, DC.

Hondo, H., Sakai, S., Tanno, S., 2002. Sensitivity analysis of total $\mathrm{CO}_{2}$ emission intensities estimated using an input-output table. Appl. Energy 72, 689-704.

Jeswani, H.K., Azapagic, A., 2011. Water footprint: Methodologies and a case study for assessing the impacts of water use. J. Clean Prod. 19 (12), 1288-1299.

Khawaji, A.D., Kutubkhanah, I.K., Wie, J.M., 2008. Advances in seawater desalination technologies. Desalin. 221, 47-69.

Kim Y.M., Kim J.H., Lee, S.H., Lee, C.K., Park, K.D., Choi, J.S., 2013. Cost comparison of pretreatment processes in large SWRO desalination plant. J. Korean Soc. Water Wastewater 27 (5), 555-560.

Kotsovinos N., Gratziou M., Tsalkatidou M., 2011. Applying the virtual water concept at regional level — The cases of the Prefectures of Xanthi and Rhodope, Greece. Desalin. Water Treat. 33 (13), 14-21.

Kramer, K.J., Moll, H.C., Nonhebel, S., Wilting, H.C., 1999. Greenhouse gas emissions related to Dutch food consumption. Energy Policy 27, 203-216.

Lenzen, M., 1999. Greenhouse gas analysis of solar-thermal electricity generation. Sol. Energy 65, $353-368$.

Lenzen, M., 2002. A guide for compiling inventories in hybrid life-cycle assessments: some Australian results. J. Clean. Prod. 10, 545-572.

Li, Y.L., Han, M.Y., 2018. Embodied water demands, transfers and imbalance of China's mega-cities. J. Clean. Prod. 1336-1345.

Linares, R.V., Li Z., Quintanilla Y.V., Ghaffour N., Amy G., Leiknes T., Vrouwenvelder J.S., 2016. Life cycle cost of a hybrid forward osmosis e low pressure reverse osmosis system for seawater desalination and wastewater recovery. Water Res. 88, 225-234.

Liu, S.Y., Han, M.Y., Wu, X.D., Wu, X.F., Li, Z., Xia, X.H., Ji, X., 2016. Embodied water analysis for Hebei Province, China by input-output modelling. Front. Earth Sci. 1-14 
Liu, S.Y., Wu, X.D., Han, M.Y., Zhang, J.J., Chen, B., Wu, X.F., Wei, W.D., Li, Z., 2017. A three-scale input-output analysis of water use in a regional economy: Hebei province in China. J. Clean. Prod.156, 962-974.

Malça, J., Freire, F., 2006. Renewability and life-cycle energy efficiency of bioethanol and bio-ethyl tertiary butyl ether (bioET BE): Assessing the implications of allocation. Energy 31, 3362-3380.

Manenti, F., Masi, M., Santucci, G., Manenti, G., 2013. Parametric simulation and economic assessment of a heat integrated geothermal desalination plant. Desalin. 317, 193-205.

Mezher, T., Fath, H., Abbas, Z., Khaled, A., 2011. Techno-economic assessment and environmental impacts of desalination technologies. Desalin. 266, 263-273.

Meng, J., Chen, G.Q., Shao, L., Li, J.S., Tang, H.S., Hayat, T., Alsaedi, A., Alsaadi, F., 2014. Virtual water accounting for building: case study for E-town, Beijing. J. Clean. Prod. 68, 7e15

Meng, J., Li, Z., Li, J.S., Shao, L., Han, M.Y., Guo, S., 2013. Embodied exergy-based assessment of energy and resource consumption of buildings. Front. Earth Sci. 8, 150-162.

Miller, R., Blair, P., 2009. Input-Output Analysis: Foundations and Extensions. Cambridge University Press, Cambridge.

Nafey, A.S., Mohamed, M.A., Sharaf, M.A., 2008. Enhancement of solar water distillation process by surfactant additives. Desalin. 220, 514-23.

National Development and Reform Commission of People's Republic of China, 2016. The 13th Five-Year Plan for the Utilization of Seawater in China, http://www.ndrc.gov.cn/zcfb/zcfbghwb/ 201612/t20161230_833749.html (in Chinese).

Proença, L.C., Ghisi, E., 2010. Water end-uses in Brazilian office buildings. Resour. Conserv. Recycl. 54, 489-500.

Qiblawey, H.M., Banat, F., 2008. Solar thermal desalination technologies. Desalin. 220, 633-644.

Shao, L., Chen, G.Q., 2013. Water Footprint Assessment for Wastewater Treatment: Method, Indicator, and Application. Enviro. Sci. Technol. 47, 7787-7794.

Shao, L., Chen, G.Q., 2016. Renewability assessment of a production system: Based on embodied energy as emergy. Renew. Sustain. Energy Rev. 57, 380-392.

State Oceanic Administration of People's Republic of China, 2017. The National Seawater Utilization Report 2016 (in Chinese). 
http://www.soa.gov.cn/zwgk/hygb/hykjnb_2186/201707/t20170719_57029.html.

Stoessel, F., Juraske, R., Pfister, S., Hellweg, S., 2012. Life cycle inventory and carbon and water foodprint of fruits and vegetables: Application to a Swiss retailer. Environ. Sci. Technol. 46 (6), $3253-3262$.

Tsiourtis, N.X., 2001. Seawater desalination projects. The Cyprus experience. Desalin. 139, 139-147. 


\section{Supplementary Materials}

\section{Appendix A}

Appendix A.1. Input list of construction engineering and its department classification.

Appendix A.2. Input list of technology system engineering and its department classification.

Appendix A.3. Input list of electrical system engineering and its department classification.

Appendix A.4. Input list of thermal system engineering and its department classification.

Appendix A.5. Input list of other services and its department classification.

\section{Appendix B}

Appendix B.1. Input list of construction engineering and its embodied water intensity (unit: $\left.\mathrm{m}^{3} /\left(10^{4} \mathrm{CNY}\right)\right)$.

Appendix B.2. Input list of technology system engineering and its embodied water intensity (unit: $\left.\mathrm{m}^{3} /\left(10^{4} \mathrm{CNY}\right)\right)$.

Appendix B.3. Input list of electrical system engineering and its embodied water intensity (unit: $\left.\mathrm{m}^{3} /\left(10^{4} \mathrm{CNY}\right)\right)$.

Appendix B.4. Input list of thermal system engineering and its embodied water intensity (unit: $\left.\mathrm{m}^{3} /\left(10^{4} \mathrm{CNY}\right)\right)$.

Appendix B.5. Input list of other services and its embodied water intensity (unit: $\mathrm{m}^{3} /\left(10^{4} \mathrm{CNY}\right)$ ).

\section{Appendix C}

Appendix C.1. Accounting of embodied water for construction engineering (unit: $\mathrm{m}^{3}$ ).

Appendix C.2. Accounting of embodied water for technology system engineering (unit: $\mathrm{m}^{3}$ ).

Appendix C.3. Accounting of embodied water for electrical system engineering (unit: $\mathrm{m}^{3}$ ).

Appendix C.4. Accounting of embodied water for thermal system engineering (unit: $\mathrm{m}^{3}$ ).

Appendix C.5. Accounting of embodied water for other services (unit: $\mathrm{m}^{3}$ ). 


\section{Appendix A}

\section{Appendix A.1}

Input list of construction engineering and its department classification.

\begin{tabular}{|c|c|c|c|}
\hline Item & Performance parameter and use & Sector code & Sector name \\
\hline $\begin{array}{c}\text { General civil engineering } \\
\text { projects }\end{array}$ & $\begin{array}{l}\text { Earthwork, masonry and pile foundation } \\
\text { etc. }\end{array}$ & 26 & Construction Industry \\
\hline Factory building & $\begin{array}{c}\text { Roads, integrated pipe racks, ditches, } \\
\text { heating pipes and factory district } \\
\text { greening }\end{array}$ & 26 & Construction Industry \\
\hline $\begin{array}{l}\text { Plumbing, Heating and } \\
\text { ventilation, Lighting }\end{array}$ & $\begin{array}{l}\text { All kinds of plumbing, Heating and } \\
\text { ventilation, Lighting facilities }\end{array}$ & 16 & $\begin{array}{c}\text { Ordinary Machinery, } \\
\text { Equipment for Special } \\
\text { Purpose }\end{array}$ \\
\hline HVAC, Fire fighting & Various fire facilities & 15 & Metal Products \\
\hline Pool & Cement, brick & 13 & $\begin{array}{c}\text { Nonmetal Mineral } \\
\text { Products }\end{array}$ \\
\hline Fire alarm system & $\begin{array}{l}\text { Device for triggering device, fire alarm } \\
\text { and other auxiliary function }\end{array}$ & 16 & $\begin{array}{c}\text { Ordinary Machinery, } \\
\text { Equipment for Special } \\
\text { Purpose }\end{array}$ \\
\hline $\begin{array}{c}\text { Automatic sprinkler system } \\
\text { of exhibit room }\end{array}$ & $\begin{array}{l}\text { Jet extinguishing fire system for } \\
\text { automatic tracking and positioning of } \\
\text { fire fighting }\end{array}$ & 16 & $\begin{array}{l}\text { Ordinary Machinery, } \\
\text { Equipment for Special } \\
\text { Purpose }\end{array}$ \\
\hline Valve-well & $\begin{array}{l}\text { Pit for placing underground pipeline and } \\
\text { underground pipeline valve }\end{array}$ & 12 & $\begin{array}{l}\text { Chemical Products } \\
\text { Related Industry }\end{array}$ \\
\hline MED bracket & $\begin{array}{l}\text { Bracket for low-temperature multi-effect } \\
\text { distillation device }\end{array}$ & 15 & Metal Products \\
\hline Auxiliary support & $\begin{array}{l}\text { The supporting bracket for auxiliary } \\
\text { device }\end{array}$ & 15 & Metal Products \\
\hline $\begin{array}{l}\text { Water supply and drainage } \\
\text { pipeline }\end{array}$ & $\begin{array}{l}\text { Used for conveying and discharging } \\
\text { seawater and freshwater }\end{array}$ & 12 & $\begin{array}{l}\text { Chemical Products } \\
\text { Related Industry }\end{array}$ \\
\hline Pipeline laying & Pipe laying, pipe installation & 26 & Construction Industry \\
\hline Foundation treatment & & 26 & Construction Industry \\
\hline PHC pipe pile & & 13 & $\begin{array}{c}\text { Nonmetal Mineral } \\
\text { Products }\end{array}$ \\
\hline Cement mixing pile & & 13 & $\begin{array}{l}\text { Nonmetal Mineral } \\
\text { Products }\end{array}$ \\
\hline Construction dewatering & Resist or lower the groundwater level & 26 & Construction Industry \\
\hline $\begin{array}{c}\text { Construction protection } \\
\text { engineering }\end{array}$ & $\begin{array}{l}\text { Protection of important equipment for } \\
\text { seawater desalination project }\end{array}$ & 26 & Construction Industry \\
\hline
\end{tabular}




\section{Appendix A.2}

Input list of technology system engineering and its department classification.

\begin{tabular}{|c|c|c|c|}
\hline Item & Performance parameter and use & Sector code & Sector name \\
\hline Evaporator & Low-temperature multi-effect evaporator & 16 & $\begin{array}{c}\text { Ordinary Machinery, } \\
\text { Equipment for Special } \\
\text { Purpose }\end{array}$ \\
\hline Stream heat compressor & & & Ordinary Machinery, \\
\hline $\begin{array}{c}\text { Water cooling system } \\
\text { equipment }\end{array}$ & & 16 & $\begin{array}{c}\text { Equipment for Special } \\
\text { Purpose }\end{array}$ \\
\hline Condenser & Horizontal two flow tube plate condenser & 16 & $\begin{array}{c}\text { Ordinary Machinery, } \\
\text { Equipment for Special } \\
\text { Purpose }\end{array}$ \\
\hline $\begin{array}{l}\text { Material water booster } \\
\text { pump }\end{array}$ & & 16 & $\begin{array}{c}\text { Ordinary Machinery, } \\
\text { Equipment for Special } \\
\text { Purpose }\end{array}$ \\
\hline Finished water pump & & 16 & $\begin{array}{c}\text { Ordinary Machinery, } \\
\text { Equipment for Special } \\
\text { Purpose }\end{array}$ \\
\hline Condensate water pump & & 16 & $\begin{array}{c}\text { Ordinary Machinery, } \\
\text { Equipment for Special } \\
\text { Purpose }\end{array}$ \\
\hline Desuperheater water pump & & 16 & $\begin{array}{c}\text { Ordinary Machinery, } \\
\text { Equipment for Special } \\
\text { Purpose }\end{array}$ \\
\hline Brine pump & & 16 & $\begin{array}{c}\text { Ordinary Machinery, } \\
\text { Equipment for Special } \\
\text { Purpose }\end{array}$ \\
\hline $\begin{array}{l}\text { Three effect stream } \\
\text { regenerative heater }\end{array}$ & & 16 & $\begin{array}{c}\text { Ordinary Machinery, } \\
\text { Equipment for Special } \\
\text { Purpose }\end{array}$ \\
\hline $\begin{array}{l}\text { Six effect stream } \\
\text { regenerative heater }\end{array}$ & & 16 & $\begin{array}{c}\text { Ordinary Machinery, } \\
\text { Equipment for Special } \\
\text { Purpose }\end{array}$ \\
\hline $\begin{array}{l}\text { Nine effect stream } \\
\text { regenerative heater }\end{array}$ & & 16 & $\begin{array}{c}\text { Ordinary Machinery, } \\
\text { Equipment for Special } \\
\text { Purpose }\end{array}$ \\
\hline $\begin{array}{c}\text { Condensation regenerative } \\
\text { heater }\end{array}$ & & 16 & $\begin{array}{c}\text { Ordinary Machinery, } \\
\text { Equipment for Special } \\
\text { Purpose }\end{array}$ \\
\hline $\begin{array}{c}\text { Seawater plate heat } \\
\text { exchanger }\end{array}$ & & 16 & $\begin{array}{c}\text { Ordinary Machinery, } \\
\text { Equipment for Special } \\
\text { Purpose }\end{array}$ \\
\hline
\end{tabular}


Input list of technology system engineering and its department classification (continued).

\begin{tabular}{|c|c|c|c|}
\hline Item & Performance parameter and use & Sector code & Sector name \\
\hline $\begin{array}{l}\text { Plate heat exchanger } \\
\text { finished water cooler }\end{array}$ & & 16 & $\begin{array}{c}\text { Ordinary Machinery, } \\
\text { Equipment for Special } \\
\text { Purpose }\end{array}$ \\
\hline Plate heat & & & Ordinary Machinery, \\
\hline exchanger condensation & & 16 & Equipment for Special \\
\hline cooler & & & Purpose \\
\hline $\begin{array}{c}\text { Automatic Back-flushing } \\
\text { Filter }\end{array}$ & & 16 & $\begin{array}{c}\text { Ordinary Machinery, } \\
\text { Equipment for Special } \\
\text { Purpose }\end{array}$ \\
\hline $\begin{array}{l}\text { Vacuum system } \\
\text { pre-condenser }\end{array}$ & & 16 & $\begin{array}{c}\text { Ordinary Machinery, } \\
\text { Equipment for Special } \\
\text { Purpose }\end{array}$ \\
\hline Start air extractor & & 16 & $\begin{array}{c}\text { Ordinary Machinery, } \\
\text { Equipment for Special } \\
\text { Purpose }\end{array}$ \\
\hline $\begin{array}{c}\text { Primary main vacuum air } \\
\text { extractor }\end{array}$ & & 16 & $\begin{array}{c}\text { Ordinary Machinery, } \\
\text { Equipment for Special } \\
\text { Purpose }\end{array}$ \\
\hline $\begin{array}{c}\text { Primary auxiliary vacuum } \\
\text { air extractor }\end{array}$ & & 16 & $\begin{array}{c}\text { Ordinary Machinery, } \\
\text { Equipment for Special } \\
\text { Purpose }\end{array}$ \\
\hline $\begin{array}{c}\text { Secondary vacuum air } \\
\text { extractor }\end{array}$ & & 16 & $\begin{array}{c}\text { Ordinary Machinery, } \\
\text { Equipment for Special } \\
\text { Purpose }\end{array}$ \\
\hline $\begin{array}{c}\text { Three - stage vacuum air } \\
\text { extractor }\end{array}$ & & 16 & $\begin{array}{c}\text { Ordinary Machinery, } \\
\text { Equipment for Special } \\
\text { Purpose }\end{array}$ \\
\hline Primary vacuum condenser & & 16 & $\begin{array}{c}\text { Ordinary Machinery, } \\
\text { Equipment for Special } \\
\text { Purpose }\end{array}$ \\
\hline $\begin{array}{l}\text { Secondary vacuum } \\
\text { condenser }\end{array}$ & & 16 & $\begin{array}{c}\text { Ordinary Machinery, } \\
\text { Equipment for Special } \\
\text { Purpose }\end{array}$ \\
\hline $\begin{array}{c}\text { Three - stage vacuum } \\
\text { condenser }\end{array}$ & & 16 & $\begin{array}{c}\text { Ordinary Machinery, } \\
\text { Equipment for Special } \\
\text { Purpose }\end{array}$ \\
\hline $\begin{array}{c}\text { Metal bellows expansion } \\
\text { joint }\end{array}$ & & 15 & Metal Products \\
\hline $\begin{array}{c}\text { Medium low pressure } \\
\text { pipeline }\end{array}$ & & 12 & $\begin{array}{l}\text { Chemical Industry } \\
\text { Related Industry }\end{array}$ \\
\hline
\end{tabular}


Input list of technology system engineering and its department classification (continued).

\begin{tabular}{|c|c|c|c|}
\hline Item & Performance parameter and use & Sector code & Sector name \\
\hline Heat treatment & & 13 & $\begin{array}{c}\text { Nonmetal Mineral } \\
\text { Products }\end{array}$ \\
\hline Seawater lift pump & $\begin{array}{c}\mathrm{Q}=5000 \mathrm{~m}^{3} / \mathrm{h} ; \mathrm{P}=0.4 \mathrm{MPa} ; \text { Electric } \\
\text { machinery: } 6 \mathrm{KV}, 800 \mathrm{KW}\end{array}$ & 16 & $\begin{array}{c}\text { Ordinary Machinery, } \\
\text { Equipment for Special } \\
\text { Purpose }\end{array}$ \\
\hline $\begin{array}{l}\text { Dosing device of } \\
\text { antifoaming agent }\end{array}$ & & 16 & $\begin{array}{c}\text { Ordinary Machinery, } \\
\text { Equipment for Special } \\
\text { Purpose }\end{array}$ \\
\hline $\begin{array}{l}\text { Dosing device of scale } \\
\text { inhibitor }\end{array}$ & & 16 & $\begin{array}{c}\text { Ordinary Machinery, } \\
\text { Equipment for Special } \\
\text { Purpose }\end{array}$ \\
\hline $\begin{array}{l}\text { Dosing device of sodium } \\
\text { sulfite agent }\end{array}$ & & 16 & $\begin{array}{c}\text { Ordinary Machinery, } \\
\text { Equipment for Special } \\
\text { Purpose }\end{array}$ \\
\hline $\begin{array}{c}\text { Seawater supply system } \\
\text { equipment }\end{array}$ & $\begin{array}{l}\text { Equipment and facilities related to water } \\
\text { supply }\end{array}$ & 16 & $\begin{array}{c}\text { Ordinary Machinery, } \\
\text { Equipment for Special } \\
\text { Purpose }\end{array}$ \\
\hline Drainage system equipment & $\begin{array}{l}\text { Drainage equipment and facilities for } \\
\text { Waste water and fresh water }\end{array}$ & 16 & $\begin{array}{c}\text { Ordinary Machinery, } \\
\text { Equipment for Special } \\
\text { Purpose }\end{array}$ \\
\hline Freshwater pump & & 16 & $\begin{array}{c}\text { Ordinary Machinery, } \\
\text { Equipment for Special } \\
\text { Purpose }\end{array}$ \\
\hline Crane equipment & & 16 & $\begin{array}{c}\text { Ordinary Machinery, } \\
\text { Equipment for Special } \\
\text { Purpose }\end{array}$ \\
\hline Valve & Used for conveying water, steam, oil, etc. & 12 & $\begin{array}{l}\text { Chemical Industry } \\
\text { Related Industry }\end{array}$ \\
\hline Brine lift pump & $\mathrm{Q}=1969 \mathrm{~m}^{3} / \mathrm{h} ; \mathrm{H}=70 \mathrm{~m} ; \mathrm{N}=500 \mathrm{~kW}$ & 16 & $\begin{array}{c}\text { Ordinary Machinery, } \\
\text { Equipment for Special } \\
\text { Purpose }\end{array}$ \\
\hline Frequency converter & & 18 & $\begin{array}{c}\text { Electric Equipment } \\
\text { and Machinery }\end{array}$ \\
\hline $\begin{array}{l}\text { Treatment of smoke } \\
\text { corrosion of crane }\end{array}$ & & 12 & $\begin{array}{l}\text { Chemical Industry } \\
\text { Related Industry }\end{array}$ \\
\hline Freshwater tank with steel & 3000 internal polyurea coating & 12 & $\begin{array}{l}\text { Chemical Industry } \\
\text { Related Industry }\end{array}$ \\
\hline Other installation materials & & 15 & Metal Products \\
\hline
\end{tabular}




\section{Appendix A.3}

Input list of electrical system engineering and its department classification.

\begin{tabular}{|c|c|c|c|}
\hline Item & Performance parameter and use & Sector code & Sector name \\
\hline \multirow{3}{*}{ 6KV Station-service power } & & \multirow{3}{*}{23} & Electric Power/Steam \\
\hline & & & and Hot Water \\
\hline & & & Production and Supply \\
\hline Low Voltage Switch Cabin & & \multirow{2}{*}{18} & Electric Equipment \\
\hline et of Drawer Model & & & and Machinery \\
\hline DC power supply panel & 110V 100Ah; Consists of 3 cabinet & 18 & $\begin{array}{c}\text { Electric Equipment } \\
\text { and Machinery }\end{array}$ \\
\hline \multirow{3}{*}{$\begin{array}{l}\text { Integrated protection and } \\
\text { monitoring device }\end{array}$} & \multirow{6}{*}{ 380V Microcomputer type } & \multirow{3}{*}{20} & Instruments, Meters \\
\hline & & & Cultural and Office \\
\hline & & & Machinery \\
\hline Cable installation & & 26 & Construction Industry \\
\hline Cable bridge support & & 15 & Metal Products \\
\hline $\begin{array}{l}\text { Other cable auxiliary } \\
\text { facility }\end{array}$ & & 15 & Metal Products \\
\hline Ground & $\begin{array}{c}\text { Grounding of power systems, electrical } \\
\text { installations, etc. }\end{array}$ & 18 & $\begin{array}{l}\text { Electric Equipment } \\
\text { and Machinery }\end{array}$ \\
\hline \multirow{3}{*}{ Communication cabling } & Supporting platform for various & \multirow{3}{*}{29} & Information \\
\hline & $\begin{array}{c}\text { information communication and } \\
\text { transmission of seawater desalination }\end{array}$ & & $\begin{array}{c}\text { Transmission, } \\
\text { Computer services and }\end{array}$ \\
\hline & system & & Software \\
\hline
\end{tabular}




\section{Appendix A.4}

Input list of thermal system engineering and its department classification.

\begin{tabular}{cccc}
\hline Item & Performance parameter and use & Sector code & Sector name \\
\hline PLC device & PLC device and corollary equipment & & $\begin{array}{c}\text { Instruments, Meters } \\
\text { Cultural and Office } \\
\text { Machinery } \\
\text { Electronic and }\end{array}$ \\
MTR-420 System server & & 20 & Telecommunications \\
Main instruments and & Instrumentation and control equipment & & Equipment \\
control equipment & for operator's inspection and operation & 20 & Instruments, Meters \\
Cubles and auxiliary & A variety of power lines and ancillary & & Machinery \\
facilities & facilities & 15 & Metal Products \\
Other installation materials & & 15 & Metal Products \\
\hline
\end{tabular}


Appendix A.5

Input list of other services and its department classification.

\begin{tabular}{lcl}
\hline \multicolumn{1}{c}{ Item } & Sector code & \multicolumn{1}{c}{ Sector name } \\
\hline Other expenses & 26 & Construction Industry \\
Management of the project construction & 36 & Polytechnic Services \\
Technical services of the project construction & 36 & Polytechnic Services \\
System commissioning and trial operation & 36 & Polytechnic Services \\
\hline
\end{tabular}




\section{Appendix B}

Appendix B.1

Input list of construction engineering and its embodied water intensity (unit: $\mathrm{m}^{3} /\left(10^{4} \mathrm{CNY}\right)$ ).

\begin{tabular}{|c|c|c|c|c|c|}
\hline \multirow[b]{2}{*}{ Item } & \multirow{2}{*}{$\begin{array}{l}\text { Sector } \\
\text { code }\end{array}$} & \multicolumn{4}{|c|}{ Embodied water intensity } \\
\hline & & $\begin{array}{l}\text { agricultural } \\
\text { production }\end{array}$ & $\begin{array}{l}\text { industrial } \\
\text { production }\end{array}$ & $\begin{array}{c}\text { household } \\
\text { use }\end{array}$ & $\begin{array}{l}\text { ecological } \\
\text { protection }\end{array}$ \\
\hline General civil engineering projects & 26 & 13.59 & 347.85 & 280.97 & 2.55 \\
\hline Factory building & 26 & 13.59 & 347.85 & 280.97 & 2.55 \\
\hline $\begin{array}{c}\text { Plumbing, Air conditioning, } \\
\text { Lighting }\end{array}$ & 16 & 14.36 & 199.42 & 151.19 & 1.66 \\
\hline HVAC, Fire fighting & 15 & 10.67 & 292.54 & 229.51 & 1.97 \\
\hline Pool & 13 & 13.60 & 227.85 & 174.10 & 2.11 \\
\hline Fire alarm system & 16 & 14.36 & 199.42 & 151.19 & 1.66 \\
\hline $\begin{array}{c}\text { Automatic sprinkler system of } \\
\text { exhibit room }\end{array}$ & 16 & 14.36 & 199.42 & 151.19 & 1.66 \\
\hline Valve-well & 12 & 46.73 & 337.65 & 264.95 & 2.47 \\
\hline MED bracket & 15 & 10.67 & 292.54 & 229.51 & 1.97 \\
\hline Auxiliary support & 15 & 10.67 & 292.54 & 229.51 & 1.97 \\
\hline $\begin{array}{c}\text { Water supply and drainage } \\
\text { pipeline }\end{array}$ & 12 & 46.73 & 337.65 & 264.95 & 2.47 \\
\hline Pipeline laying & 26 & 13.59 & 347.85 & 280.97 & 2.55 \\
\hline Foundation treatment & 26 & 13.59 & 347.85 & 280.97 & 2.55 \\
\hline PHC pipe pile & 13 & 13.60 & 227.85 & 174.10 & 2.11 \\
\hline Cement mixing pile & 13 & 13.60 & 227.85 & 174.10 & 2.11 \\
\hline Construction dewatering & 26 & 13.59 & 347.85 & 280.97 & 2.55 \\
\hline $\begin{array}{l}\text { Construction protection } \\
\text { engineering }\end{array}$ & 26 & 13.59 & 347.85 & 280.97 & 2.55 \\
\hline
\end{tabular}




\section{Appendix B.2}

Input list of technology system engineering and its embodied water intensity (unit: $\mathrm{m}^{3} /\left(10^{4} \mathrm{CNY}\right)$ ).

\begin{tabular}{|c|c|c|c|c|c|}
\hline \multirow[b]{2}{*}{ Item } & \multirow{2}{*}{$\begin{array}{l}\text { Sector } \\
\text { code }\end{array}$} & \multicolumn{4}{|c|}{ Embodied water intensity } \\
\hline & & $\begin{array}{l}\text { agricultural } \\
\text { production }\end{array}$ & $\begin{array}{l}\text { industrial } \\
\text { production }\end{array}$ & $\begin{array}{c}\text { household } \\
\text { use }\end{array}$ & $\begin{array}{l}\text { ecological } \\
\text { protection }\end{array}$ \\
\hline Evaporator & 16 & 14.36 & 199.42 & 151.19 & 1.66 \\
\hline $\begin{array}{c}\text { Steam heat compressor } \\
\text { Water cooling system equipment }\end{array}$ & 16 & 14.36 & 199.42 & 151.19 & 1.66 \\
\hline Condenser & 16 & 14.36 & 199.42 & 151.19 & 1.66 \\
\hline Material water booster pump & 16 & 14.36 & 199.42 & 151.19 & 1.66 \\
\hline Finished water pump & 16 & 14.36 & 199.42 & 151.19 & 1.66 \\
\hline Condensate water pump & 16 & 14.36 & 199.42 & 151.19 & 1.66 \\
\hline Desuperheater water pump & 16 & 14.36 & 199.42 & 151.19 & 1.66 \\
\hline Brine pump & 16 & 14.36 & 199.42 & 151.19 & 1.66 \\
\hline $\begin{array}{c}\text { Three effect stream regenerative } \\
\text { heater }\end{array}$ & 16 & 14.36 & 199.42 & 151.19 & 1.66 \\
\hline $\begin{array}{c}\text { Six effect stream regenerative } \\
\text { heater }\end{array}$ & 16 & 14.36 & 199.42 & 151.19 & 1.66 \\
\hline $\begin{array}{c}\text { Nine effect stream regenerative } \\
\text { heater }\end{array}$ & 16 & 14.36 & 199.42 & 151.19 & 1.66 \\
\hline Condensation regenerative heater & 16 & 14.36 & 199.42 & 151.19 & 1.66 \\
\hline Seawater plate heat exchanger & 16 & 14.36 & 199.42 & 151.19 & 1.66 \\
\hline $\begin{array}{l}\text { Plate heat exchanger finished } \\
\text { water cooler }\end{array}$ & 16 & 14.36 & 199.42 & 151.19 & 1.66 \\
\hline $\begin{array}{l}\text { Plate heat } \\
\text { exchanger condensation cooler }\end{array}$ & 16 & 14.36 & 199.42 & 151.19 & 1.66 \\
\hline Automatic Back-flushing Filter & 16 & 14.36 & 199.42 & 151.19 & 1.66 \\
\hline Vacuum system pre-condenser & 16 & 14.36 & 199.42 & 151.19 & 1.66 \\
\hline Start air extractor & 16 & 14.36 & 199.42 & 151.19 & 1.66 \\
\hline $\begin{array}{l}\text { Primary main vacuum air } \\
\text { extractor }\end{array}$ & 16 & 14.36 & 199.42 & 151.19 & 1.66 \\
\hline $\begin{array}{c}\text { Primary auxiliary vacuum air } \\
\text { extractor }\end{array}$ & 16 & 14.36 & 199.42 & 151.19 & 1.66 \\
\hline Secondary vacuum air extractor & 16 & 14.36 & 199.42 & 151.19 & 1.66 \\
\hline $\begin{array}{c}\text { Three - stage vacuum air } \\
\text { extractor }\end{array}$ & 16 & 14.36 & 199.42 & 151.19 & 1.66 \\
\hline Primary vacuum condenser & 16 & 14.36 & 199.42 & 151.19 & 1.66 \\
\hline Secondary vacuum condenser & 16 & 14.36 & 199.42 & 151.19 & 1.66 \\
\hline Three - stage vacuum condenser & 16 & 14.36 & 199.42 & 151.19 & 1.66 \\
\hline Metal bellows expansion joint & 15 & 10.67 & 292.54 & 229.51 & 1.97 \\
\hline Medium low pressure pipeline & 12 & 46.73 & 337.65 & 264.95 & 2.47 \\
\hline Heat treatment & 13 & 13.60 & 227.85 & 174.10 & 2.11 \\
\hline Seawater lift pump & 16 & 14.36 & 199.42 & 151.19 & 1.66 \\
\hline
\end{tabular}


Input list of technology system engineering and its embodied water intensity (unit: $\mathrm{m}^{3} /\left(10^{4} \mathrm{CNY}\right)$ ) (continued).

\begin{tabular}{|c|c|c|c|c|c|}
\hline \multirow[b]{2}{*}{ Item } & \multirow{2}{*}{$\begin{array}{l}\text { Sector } \\
\text { code }\end{array}$} & \multicolumn{4}{|c|}{ Embodied water intensity } \\
\hline & & $\begin{array}{l}\text { agricultural } \\
\text { production }\end{array}$ & $\begin{array}{l}\text { industrial } \\
\text { production }\end{array}$ & $\begin{array}{c}\text { household } \\
\text { use }\end{array}$ & $\begin{array}{l}\text { ecological } \\
\text { protection }\end{array}$ \\
\hline $\begin{array}{c}\text { Dosing device of antifoaming } \\
\text { agent }\end{array}$ & 16 & 14.36 & 199.42 & 151.19 & 1.66 \\
\hline Dosing device of scale inhibitor & 16 & 14.36 & 199.42 & 151.19 & 1.66 \\
\hline $\begin{array}{c}\text { Dosing device of sodium sulfite } \\
\text { agent }\end{array}$ & 16 & 14.36 & 199.42 & 151.19 & 1.66 \\
\hline $\begin{array}{c}\text { Seawater supply system } \\
\text { equipment }\end{array}$ & 16 & 14.36 & 199.42 & 151.19 & 1.66 \\
\hline Drainage system equipment & 16 & 14.36 & 199.42 & 151.19 & 1.66 \\
\hline Freshwater pump & 16 & 14.36 & 199.42 & 151.19 & 1.66 \\
\hline Crane equipment & 16 & 14.36 & 199.42 & 151.19 & 1.66 \\
\hline Valve & 12 & 46.73 & 337.65 & 264.95 & 2.47 \\
\hline Brine lift pump & 16 & 14.36 & 199.42 & 151.19 & 1.66 \\
\hline Frequency converter & 18 & 13.06 & 193.61 & 146.62 & 1.52 \\
\hline $\begin{array}{c}\text { Treatment of smoke corrosion of } \\
\text { crane }\end{array}$ & 12 & 46.73 & 337.65 & 264.95 & 2.47 \\
\hline Freshwater tank with steel & 12 & 46.73 & 337.65 & 264.95 & 2.47 \\
\hline Other installation materials & 15 & 10.67 & 292.54 & 229.51 & 1.97 \\
\hline
\end{tabular}




\section{Appendix B.3}

Input list of electrical system engineering and its embodied water intensity (unit: $\mathrm{m}^{3} /\left(10^{4} \mathrm{CNY}\right)$ ).

\begin{tabular}{|c|c|c|c|c|c|}
\hline \multirow[b]{2}{*}{ Item } & \multirow{2}{*}{$\begin{array}{l}\text { Sector } \\
\text { code }\end{array}$} & \multicolumn{4}{|c|}{ Embodied water intensity } \\
\hline & & $\begin{array}{l}\text { agricultural } \\
\text { production }\end{array}$ & $\begin{array}{l}\text { industrial } \\
\text { production }\end{array}$ & $\begin{array}{c}\text { household } \\
\text { use }\end{array}$ & $\begin{array}{l}\text { ecological } \\
\text { protection }\end{array}$ \\
\hline 6KV Station-service power & 23 & 8.82 & 562.49 & 418.55 & 3.57 \\
\hline $\begin{array}{c}\text { Low Voltage Switch Cabinet of } \\
\text { Drawer Model }\end{array}$ & 18 & 13.06 & 193.61 & 146.62 & 1.52 \\
\hline DC power supply panel & 18 & 13.06 & 193.61 & 146.62 & 1.52 \\
\hline $\begin{array}{c}\text { Integrated protection and monitor } \\
\text { ing device }\end{array}$ & 20 & 19.46 & 127.29 & 92.23 & 1.24 \\
\hline Cable installation & 26 & 13.59 & 347.85 & 280.97 & 2.55 \\
\hline Cable bridge support & 15 & 10.67 & 292.54 & 229.51 & 1.97 \\
\hline Other cable auxiliary facility & 15 & 10.67 & 292.54 & 229.51 & 1.97 \\
\hline Ground & 18 & 13.06 & 193.61 & 146.62 & 1.52 \\
\hline Communication cabling & 29 & 4.02 & 39.22 & 31.42 & 0.40 \\
\hline
\end{tabular}




\section{Appendix B.4}

Input list of thermal system engineering and its embodied water intensity (unit: $\mathrm{m}^{3} /\left(10^{4} \mathrm{CNY}\right)$ ).

\begin{tabular}{cccccc}
\hline & Sector & \multicolumn{4}{c}{ Embodied water intensity } \\
\cline { 3 - 6 } Item & code & $\begin{array}{c}\text { agricultural } \\
\text { production }\end{array}$ & $\begin{array}{c}\text { industrial } \\
\text { production }\end{array}$ & $\begin{array}{c}\text { household } \\
\text { use }\end{array}$ & $\begin{array}{c}\text { ecological } \\
\text { protection }\end{array}$ \\
\hline PLC device & 20 & 19.46 & 127.29 & 92.23 & 1.24 \\
MTR-420 System server & 19 & 16.62 & 226.76 & 174.40 & 1.68 \\
Main instruments and control & 20 & 19.46 & 127.29 & 92.23 & 1.24 \\
$\quad$ equipment & 15 & 10.67 & 292.54 & 229.51 & 1.97 \\
Cables and auxiliary facilities & 15 & 10.67 & 292.54 & 229.51 & 1.97 \\
\hline Other installation materials & 15 & &
\end{tabular}




\section{Appendix B.5}

Input list of other services and its embodied water intensity (unit: $\mathrm{m}^{3} /\left(10^{4} \mathrm{CNY}\right)$ ).

\begin{tabular}{cccccc}
\hline & Sector & \multicolumn{4}{c}{ Embodied water intensity } \\
\cline { 3 - 5 } Item & code & $\begin{array}{c}\text { agricultural } \\
\text { production }\end{array}$ & $\begin{array}{c}\text { industrial } \\
\text { production }\end{array}$ & $\begin{array}{c}\text { household } \\
\text { use }\end{array}$ & $\begin{array}{c}\text { ecological } \\
\text { protection }\end{array}$ \\
\hline $\begin{array}{c}\text { Other expenses } \\
\text { Management of the project }\end{array}$ & 26 & 13.59 & 347.85 & 280.97 & 2.55 \\
$\begin{array}{c}\text { construction } \\
\begin{array}{c}\text { Technical services of the project } \\
\text { construction }\end{array}\end{array}$ & 36 & 14.15 & 154.62 & 123.65 & 1.41 \\
$\begin{array}{c}\text { System commissioning and trial } \\
\text { operation }\end{array}$ & 36 & 14.15 & 154.62 & 123.65 & 1.41 \\
\hline
\end{tabular}




\section{Appendix C}

\section{Appendix C.1}

Accounting of embodied water for construction engineering (unit: $\mathrm{m}^{3}$ ).

\begin{tabular}{|c|c|c|c|c|c|}
\hline \multirow[b]{2}{*}{ Item } & \multirow{2}{*}{$\begin{array}{l}\text { Sector } \\
\text { code }\end{array}$} & \multicolumn{4}{|c|}{ Embodied water consumption } \\
\hline & & $\begin{array}{c}\text { agricultural } \\
\text { production }\end{array}$ & $\begin{array}{l}\text { industrial } \\
\text { production }\end{array}$ & $\begin{array}{c}\text { household } \\
\text { use }\end{array}$ & $\begin{array}{l}\text { ecological } \\
\text { protection }\end{array}$ \\
\hline $\begin{array}{c}\text { General civil engineering } \\
\text { projects }\end{array}$ & 26 & $1.70 \mathrm{E}+04$ & $4.36 \mathrm{E}+05$ & $3.52 \mathrm{E}+05$ & $3.20 \mathrm{E}+03$ \\
\hline Factory building & 26 & $2.13 \mathrm{E}+03$ & $5.45 \mathrm{E}+04$ & $4.40 \mathrm{E}+04$ & $4.00 \mathrm{E}+02$ \\
\hline $\begin{array}{c}\text { Plumbing, Air conditioning, } \\
\text { Lighting }\end{array}$ & 16 & $8.63 \mathrm{E}+02$ & $1.20 \mathrm{E}+04$ & $9.08 \mathrm{E}+03$ & $9.96 \mathrm{E}+01$ \\
\hline HVAC, Fire fighting & 15 & $1.98 \mathrm{E}+03$ & $5.43 \mathrm{E}+04$ & $4.26 \mathrm{E}+04$ & $3.66 \mathrm{E}+02$ \\
\hline Pool & 13 & $7.08 \mathrm{E}+03$ & $1.19 \mathrm{E}+05$ & $9.07 \mathrm{E}+04$ & $1.10 \mathrm{E}+03$ \\
\hline Fire alarm system & 16 & $6.94 \mathrm{E}+02$ & $9.63 \mathrm{E}+03$ & $7.30 \mathrm{E}+03$ & $8.01 \mathrm{E}+01$ \\
\hline $\begin{array}{c}\text { Automatic sprinkler system of } \\
\text { exhibit room }\end{array}$ & 16 & $1.96 \mathrm{E}+02$ & $2.72 \mathrm{E}+03$ & $2.07 \mathrm{E}+03$ & $2.27 \mathrm{E}+01$ \\
\hline Valve-well & 12 & $1.20 \mathrm{E}+03$ & $8.64 \mathrm{E}+03$ & $6.78 \mathrm{E}+03$ & $6.31 \mathrm{E}+01$ \\
\hline MED bracket & 15 & $1.02 \mathrm{E}+03$ & $2.79 \mathrm{E}+04$ & $2.19 \mathrm{E}+04$ & $1.88 \mathrm{E}+02$ \\
\hline Auxiliary support & 15 & $3.99 \mathrm{E}+02$ & $1.09 \mathrm{E}+04$ & $8.59 \mathrm{E}+03$ & $7.38 \mathrm{E}+01$ \\
\hline $\begin{array}{c}\text { Water supply and drainage } \\
\text { pipeline }\end{array}$ & 12 & $6.49 \mathrm{E}+03$ & $4.69 \mathrm{E}+04$ & $3.68 \mathrm{E}+04$ & $3.42 \mathrm{E}+02$ \\
\hline Pipeline laying & 26 & $7.85 \mathrm{E}+02$ & $2.01 \mathrm{E}+04$ & $1.62 \mathrm{E}+04$ & $1.47 \mathrm{E}+02$ \\
\hline Foundation treatment & 26 & $6.82 \mathrm{E}+03$ & $1.75 \mathrm{E}+05$ & $1.41 \mathrm{E}+05$ & $1.28 \mathrm{E}+03$ \\
\hline PHC pipe pile & 13 & $2.80 \mathrm{E}+02$ & $4.69 \mathrm{E}+03$ & $3.59 \mathrm{E}+03$ & $4.35 \mathrm{E}+01$ \\
\hline Cement mixing pile & 13 & $2.06 \mathrm{E}+03$ & $3.46 \mathrm{E}+04$ & $2.64 \mathrm{E}+04$ & $3.20 \mathrm{E}+02$ \\
\hline Construction dewatering & 26 & $3.48 \mathrm{E}+03$ & $8.91 \mathrm{E}+04$ & $7.20 \mathrm{E}+04$ & $6.54 \mathrm{E}+02$ \\
\hline $\begin{array}{c}\text { Construction protection } \\
\text { engineering }\end{array}$ & 26 & $8.03 \mathrm{E}+02$ & $2.06 \mathrm{E}+04$ & $1.66 \mathrm{E}+04$ & $1.51 \mathrm{E}+02$ \\
\hline
\end{tabular}




\section{Appendix C.2}

Accounting of embodied water for technology system engineering (unit: $\mathrm{m}^{3}$ ).

\begin{tabular}{|c|c|c|c|c|c|}
\hline \multirow[b]{2}{*}{ Item } & \multirow[b]{2}{*}{$\begin{array}{l}\text { Sector } \\
\text { code }\end{array}$} & \multicolumn{4}{|c|}{ Embodied water consumption } \\
\hline & & $\begin{array}{l}\text { agricultural } \\
\text { production }\end{array}$ & $\begin{array}{l}\text { industrial } \\
\text { production }\end{array}$ & $\begin{array}{c}\text { household } \\
\text { use }\end{array}$ & $\begin{array}{l}\text { ecological } \\
\text { protection }\end{array}$ \\
\hline Evaporator & 16 & $4.76 \mathrm{E}+03$ & $6.61 \mathrm{E}+04$ & $5.01 \mathrm{E}+04$ & $5.49 \mathrm{E}+02$ \\
\hline Steam heat compressor & & & & & \\
\hline $\begin{array}{l}\text { Water cooling system } \\
\text { equipment }\end{array}$ & 16 & $4.01 \mathrm{E}+03$ & $5.57 \mathrm{E}+04$ & $4.22 \mathrm{E}+04$ & $4.63 \mathrm{E}+02$ \\
\hline Condenser & 16 & $4.32 \mathrm{E}+03$ & $6.00 \mathrm{E}+04$ & $4.55 \mathrm{E}+04$ & $4.99 \mathrm{E}+02$ \\
\hline Material water booster pump & 16 & $1.99 \mathrm{E}+02$ & $2.76 \mathrm{E}+03$ & $2.09 \mathrm{E}+03$ & $2.30 \mathrm{E}+01$ \\
\hline Finished water pump & 16 & $5.93 \mathrm{E}+01$ & $8.23 \mathrm{E}+02$ & $6.24 \mathrm{E}+02$ & $6.84 \mathrm{E}+00$ \\
\hline Condensate water pump & 16 & $1.17 \mathrm{E}+05$ & $1.63 \mathrm{E}+06$ & $1.23 \mathrm{E}+06$ & $1.35 \mathrm{E}+04$ \\
\hline Desuperheater water pump & 16 & $9.26 \mathrm{E}+03$ & $1.29 \mathrm{E}+05$ & $9.75 \mathrm{E}+04$ & $1.07 \mathrm{E}+03$ \\
\hline Brine pump & 16 & $5.26 \mathrm{E}+02$ & $7.30 \mathrm{E}+03$ & $5.53 \mathrm{E}+03$ & $6.07 \mathrm{E}+01$ \\
\hline $\begin{array}{l}\text { Three effect stream } \\
\text { regenerative heater }\end{array}$ & 16 & $1.80 \mathrm{E}+03$ & $2.50 \mathrm{E}+04$ & $1.90 \mathrm{E}+04$ & $2.08 \mathrm{E}+02$ \\
\hline $\begin{array}{c}\text { Six effect stream regenerative } \\
\text { heater }\end{array}$ & 16 & $1.13 \mathrm{E}+02$ & $1.56 \mathrm{E}+03$ & $1.19 \mathrm{E}+03$ & $1.30 \mathrm{E}+01$ \\
\hline $\begin{array}{c}\text { Nine effect stream regenerative } \\
\text { heater }\end{array}$ & 16 & $5.33 \mathrm{E}+02$ & $7.40 \mathrm{E}+03$ & $5.61 \mathrm{E}+03$ & $6.15 \mathrm{E}+01$ \\
\hline $\begin{array}{c}\text { Condensation regenerative } \\
\text { heater }\end{array}$ & 16 & $1.37 \mathrm{E}+02$ & $1.90 \mathrm{E}+03$ & $1.44 \mathrm{E}+03$ & $1.58 \mathrm{E}+01$ \\
\hline Seawater plate heat exchanger & 16 & $1.43 \mathrm{E}+03$ & $1.99 \mathrm{E}+04$ & $1.51 \mathrm{E}+04$ & $1.66 \mathrm{E}+02$ \\
\hline $\begin{array}{l}\text { Plate heat exchanger finished } \\
\text { water cooler }\end{array}$ & 16 & 7.17E+01 & $9.95 \mathrm{E}+02$ & $7.55 \mathrm{E}+02$ & $8.28 \mathrm{E}+00$ \\
\hline $\begin{array}{l}\text { Plate heat } \\
\text { exchanger condensation cooler }\end{array}$ & 16 & $1.67 \mathrm{E}+02$ & $2.32 \mathrm{E}+03$ & $1.76 \mathrm{E}+03$ & $1.93 \mathrm{E}+01$ \\
\hline Automatic Back-flushing Filter & 16 & $1.19 \mathrm{E}+02$ & $1.66 \mathrm{E}+03$ & $1.26 \mathrm{E}+03$ & $1.38 \mathrm{E}+01$ \\
\hline Vacuum system pre-condenser & 16 & $1.52 \mathrm{E}+01$ & $2.11 \mathrm{E}+02$ & $1.60 \mathrm{E}+02$ & $1.76 \mathrm{E}+00$ \\
\hline Start air extractor & 16 & $8.30 \mathrm{E}+02$ & $1.15 \mathrm{E}+04$ & $8.74 \mathrm{E}+03$ & $9.58 \mathrm{E}+01$ \\
\hline $\begin{array}{l}\text { Primary main vacuum air } \\
\text { extractor }\end{array}$ & 16 & $2.49 \mathrm{E}+03$ & $3.46 \mathrm{E}+04$ & $2.62 \mathrm{E}+04$ & $2.88 \mathrm{E}+02$ \\
\hline $\begin{array}{c}\text { Primary auxiliary vacuum air } \\
\text { extractor }\end{array}$ & 16 & $8.56 \mathrm{E}+02$ & $1.19 \mathrm{E}+04$ & $9.01 \mathrm{E}+03$ & $9.89 \mathrm{E}+01$ \\
\hline Secondary vacuum air extractor & 16 & $9.22 \mathrm{E}+02$ & $1.28 \mathrm{E}+04$ & $9.71 \mathrm{E}+03$ & $1.06 \mathrm{E}+02$ \\
\hline $\begin{array}{c}\text { Three - stage vacuum air } \\
\text { extractor }\end{array}$ & 16 & $7.97 \mathrm{E}+01$ & $1.11 \mathrm{E}+03$ & $8.39 \mathrm{E}+02$ & $9.21 \mathrm{E}+00$ \\
\hline Primary vacuum condenser & 16 & $2.04 \mathrm{E}+02$ & $2.83 \mathrm{E}+03$ & $2.15 \mathrm{E}+03$ & $2.35 \mathrm{E}+01$ \\
\hline Secondary vacuum condenser & 16 & $1.33 \mathrm{E}+02$ & $1.84 \mathrm{E}+03$ & $1.40 \mathrm{E}+03$ & $1.53 \mathrm{E}+01$ \\
\hline Three - stage vacuum condenser & 16 & $1.49 \mathrm{E}+01$ & $2.07 \mathrm{E}+02$ & $1.57 \mathrm{E}+02$ & $1.72 \mathrm{E}+00$ \\
\hline Metal bellows expansion joint & 15 & $5.27 \mathrm{E}+01$ & $1.44 \mathrm{E}+03$ & $1.13 \mathrm{E}+03$ & $9.74 \mathrm{E}+00$ \\
\hline
\end{tabular}


Accounting of embodied water for technology system engineering (unit: $\mathrm{m}^{3}$ ) (continued).

\begin{tabular}{|c|c|c|c|c|c|}
\hline \multirow[b]{2}{*}{ Item } & \multirow{2}{*}{$\begin{array}{l}\text { Sector } \\
\text { code }\end{array}$} & \multicolumn{4}{|c|}{ Embodied water consumption } \\
\hline & & $\begin{array}{l}\text { agricultural } \\
\text { production }\end{array}$ & $\begin{array}{l}\text { industrial } \\
\text { production }\end{array}$ & $\begin{array}{c}\text { household } \\
\text { use }\end{array}$ & $\begin{array}{l}\text { ecological } \\
\text { protection }\end{array}$ \\
\hline Medium low pressure pipeline & 12 & $1.31 \mathrm{E}+02$ & $9.45 \mathrm{E}+02$ & $7.42 \mathrm{E}+02$ & $6.90 \mathrm{E}+00$ \\
\hline Heat treatment & 13 & $1.05 \mathrm{E}+03$ & $1.76 \mathrm{E}+04$ & $1.35 \mathrm{E}+04$ & $1.63 \mathrm{E}+02$ \\
\hline Seawater lift pump & 16 & $4.96 \mathrm{E}+02$ & $6.89 \mathrm{E}+03$ & $5.23 \mathrm{E}+03$ & $5.73 \mathrm{E}+01$ \\
\hline $\begin{array}{c}\text { Dosing device of antifoaming } \\
\text { agent }\end{array}$ & 16 & $2.96 \mathrm{E}+02$ & $4.11 \mathrm{E}+03$ & $3.11 \mathrm{E}+03$ & $3.41 \mathrm{E}+01$ \\
\hline Dosing device of scale inhibitor & 16 & $1.15 \mathrm{E}+02$ & $1.60 \mathrm{E}+03$ & $1.21 \mathrm{E}+03$ & $1.33 \mathrm{E}+01$ \\
\hline $\begin{array}{c}\text { Dosing device of sodium sulfite } \\
\text { agent }\end{array}$ & 16 & $1.36 \mathrm{E}+04$ & $1.89 \mathrm{E}+05$ & $1.44 \mathrm{E}+05$ & $1.58 \mathrm{E}+03$ \\
\hline $\begin{array}{c}\text { Seawater supply system } \\
\text { equipment }\end{array}$ & 16 & $3.38 \mathrm{E}+03$ & $4.69 \mathrm{E}+04$ & $3.56 \mathrm{E}+04$ & $3.90 \mathrm{E}+02$ \\
\hline Drainage system equipment & 16 & $3.09 \mathrm{E}+03$ & $4.29 \mathrm{E}+04$ & $3.25 \mathrm{E}+04$ & $3.57 \mathrm{E}+02$ \\
\hline Freshwater pump & 16 & $3.11 \mathrm{E}+02$ & $4.32 \mathrm{E}+03$ & $3.27 \mathrm{E}+03$ & $3.59 \mathrm{E}+01$ \\
\hline Crane equipment & 16 & $3.38 \mathrm{E}+02$ & $4.69 \mathrm{E}+03$ & $3.56 \mathrm{E}+03$ & $3.90 \mathrm{E}+01$ \\
\hline Valve & 12 & $7.52 \mathrm{E}+02$ & $5.44 \mathrm{E}+03$ & $4.27 \mathrm{E}+03$ & $3.97 \mathrm{E}+01$ \\
\hline Brine lift pump & 16 & $1.37 \mathrm{E}+04$ & $1.90 \mathrm{E}+05$ & $1.44 \mathrm{E}+05$ & $1.58 \mathrm{E}+03$ \\
\hline Frequency converter & 18 & $1.47 \mathrm{E}+03$ & $2.18 \mathrm{E}+04$ & $1.65 \mathrm{E}+04$ & $1.72 \mathrm{E}+02$ \\
\hline $\begin{array}{l}\text { Treatment of smoke corrosion } \\
\text { of crane }\end{array}$ & 12 & $6.44 \mathrm{E}+03$ & $4.65 \mathrm{E}+04$ & $3.65 \mathrm{E}+04$ & $3.40 \mathrm{E}+02$ \\
\hline Freshwater tank with steel & 12 & $1.25 \mathrm{E}+03$ & $9.01 \mathrm{E}+03$ & $7.07 \mathrm{E}+03$ & $6.58 \mathrm{E}+01$ \\
\hline Other installation materials & 15 & $9.78 \mathrm{E}+03$ & $2.68 \mathrm{E}+05$ & $2.10 \mathrm{E}+05$ & $1.81 \mathrm{E}+03$ \\
\hline
\end{tabular}




\section{Appendix C.3}

Accounting of embodied water for electrical system engineering (unit: $\mathrm{m}^{3}$ ).

\begin{tabular}{|c|c|c|c|c|c|}
\hline \multirow[b]{2}{*}{ Item } & \multirow{2}{*}{$\begin{array}{l}\text { Sector } \\
\text { code }\end{array}$} & \multicolumn{4}{|c|}{ Embodied water consumption } \\
\hline & & $\begin{array}{l}\text { agricultural } \\
\text { production }\end{array}$ & $\begin{array}{l}\text { industrial } \\
\text { production }\end{array}$ & $\begin{array}{c}\text { household } \\
\text { use }\end{array}$ & $\begin{array}{l}\text { ecological } \\
\text { protection }\end{array}$ \\
\hline $6 \mathrm{KV}$ Station-service power & 23 & $2.16 \mathrm{E}+03$ & $1.38 \mathrm{E}+05$ & $1.02 \mathrm{E}+05$ & $8.75 \mathrm{E}+02$ \\
\hline $\begin{array}{c}\text { Low Voltage Switch Cabinet of } \\
\text { Drawer Model }\end{array}$ & 18 & $3.80 \mathrm{E}+03$ & $5.64 \mathrm{E}+04$ & $4.27 \mathrm{E}+04$ & $4.44 \mathrm{E}+02$ \\
\hline DC power supply panel & 18 & $6.79 \mathrm{E}+00$ & $1.01 \mathrm{E}+02$ & $7.62 \mathrm{E}+01$ & 7.92E-01 \\
\hline $\begin{array}{c}\text { Integrated protection and monit } \\
\text { oring device }\end{array}$ & 20 & $1.64 \mathrm{E}+04$ & $1.07 \mathrm{E}+05$ & $7.77 \mathrm{E}+04$ & $1.05 \mathrm{E}+03$ \\
\hline Cable installation & 26 & $1.35 \mathrm{E}+02$ & $3.44 \mathrm{E}+03$ & $2.78 \mathrm{E}+03$ & $2.53 \mathrm{E}+01$ \\
\hline Cable bridge support & 15 & $3.20 \mathrm{E}+03$ & $8.76 \mathrm{E}+04$ & $6.87 \mathrm{E}+04$ & $5.91 \mathrm{E}+02$ \\
\hline Other cable auxiliary facility & 15 & $1.99 \mathrm{E}+03$ & $5.45 \mathrm{E}+04$ & $4.27 \mathrm{E}+04$ & $3.67 \mathrm{E}+02$ \\
\hline Ground & 18 & $1.20 \mathrm{E}+02$ & $1.78 \mathrm{E}+03$ & $1.35 \mathrm{E}+03$ & $1.40 \mathrm{E}+01$ \\
\hline Communication cabling & 29 & $1.20 \mathrm{E}+02$ & $1.18 \mathrm{E}+03$ & $9.42 \mathrm{E}+02$ & $1.21 \mathrm{E}+01$ \\
\hline
\end{tabular}




\section{Appendix C.4}

Accounting of embodied water for thermal system engineering (unit: $\mathrm{m}^{3}$ ).

\begin{tabular}{cccccc}
\hline & & \multicolumn{3}{c}{ Embodied water consumption } \\
\cline { 3 - 5 } Item & Sector code & $\begin{array}{c}\text { agricultural } \\
\text { production }\end{array}$ & $\begin{array}{c}\text { industrial } \\
\text { production }\end{array}$ & $\begin{array}{c}\text { household } \\
\text { use }\end{array}$ & $\begin{array}{c}\text { ecological } \\
\text { protection }\end{array}$ \\
\hline $\begin{array}{c}\text { PLC device } \\
\text { MTR-420 System server }\end{array}$ & 20 & $9.06 \mathrm{E}+03$ & $5.92 \mathrm{E}+04$ & $4.29 \mathrm{E}+04$ & $5.79 \mathrm{E}+02$ \\
$\begin{array}{c}\text { Main instruments and control } \\
\text { equipment }\end{array}$ & 19 & $7.58 \mathrm{E}+02$ & $1.03 \mathrm{E}+04$ & $7.96 \mathrm{E}+03$ & $7.67 \mathrm{E}+01$ \\
Cables and auxiliary facilities & 15 & $1.81 \mathrm{E}+02$ & $1.19 \mathrm{E}+03$ & $8.60 \mathrm{E}+02$ & $1.16 \mathrm{E}+01$ \\
Other installation materials & 15 & $2.35 \mathrm{E}+02$ & $6.44 \mathrm{E}+03$ & $5.05 \mathrm{E}+03$ & $4.34 \mathrm{E}+01$ \\
\hline
\end{tabular}




\section{Appendix C.5}

Accounting of embodied water for other services (unit: $\mathrm{m}^{3}$ ).

\begin{tabular}{cccccc}
\hline & Sector code & \multicolumn{3}{c}{ Embodied water consumption } \\
\cline { 3 - 5 } Item & & $\begin{array}{c}\text { agricultural } \\
\text { production }\end{array}$ & $\begin{array}{c}\text { industrial } \\
\text { production }\end{array}$ & $\begin{array}{c}\text { household } \\
\text { use }\end{array}$ & $\begin{array}{c}\text { ecological } \\
\text { protection }\end{array}$ \\
\hline $\begin{array}{c}\text { Other expenses } \\
\text { Management of the project } \\
\text { construction }\end{array}$ & 26 & $3.57 \mathrm{E}+03$ & $9.14 \mathrm{E}+04$ & $7.38 \mathrm{E}+04$ & $6.71 \mathrm{E}+02$ \\
$\begin{array}{c}\text { Technical services of the } \\
\text { project construction }\end{array}$ & 36 & $2.35 \mathrm{E}+03$ & $2.57 \mathrm{E}+04$ & $2.06 \mathrm{E}+04$ & $2.34 \mathrm{E}+02$ \\
$\begin{array}{c}\text { System commissioning and } \\
\text { trial operation }\end{array}$ & 36 & $1.47 \mathrm{E}+04$ & $1.61 \mathrm{E}+05$ & $1.28 \mathrm{E}+05$ & $1.46 \mathrm{E}+03$ \\
\hline
\end{tabular}

